\title{
Minority Shareholders' Wealth Effects and Stock Market Development: Evidence from Increase-in-Ownership M\&As
}

\author{
Ettore Croci ${ }^{\mathrm{a}}{ }^{*}$ \\ Dimitris Petmezas ${ }^{\mathrm{b}}$ \\ a Università degli Studi di Milano-Bicocca, Facoltà di Economia, Dipartimento di Scienze \\ Economico-Aziendali, Piazza dell'Ateneo Nuovo, 1 ed. U6, 20126 Milan, Italy. \\ ${ }^{\mathrm{b}}$ University of Surrey, School of Management, Guildford, Surrey, GU2 7XH, UK
}

This Version: August 2009

\begin{abstract}
This paper examines, using a global M\&A data set, the relationship between the target firm's minority shareholders' returns and a country's stock market development in deals in which large shareholders increase their ownership stakes. For the purpose of this study, we use two measures of stock market development: (1) turnover over GDP, and (2) turnover over market capitalization. We provide evidence supporting the view that minority shareholders in target firms gain significantly more in countries with high stock market development than their counterparts in less-developed markets. Our results are robust to several firm and deal characteristics and provide evidence to policy makers that the degree of stock market development is a key determinant in improving minority shareholders' welfare.
\end{abstract}

JEL classification code: G34

Keywords: minority shareholders; stock market development; increase-in-ownership mergers and acquisitions; target returns

*Corresponding author: Tel.: +39 0264483152

E-mail addresses: ettore.croci@unimib.it (E.Croci); d.petmezas@surrey.ac.uk (D. Petmezas)

Financial support by MIUR - PRIN 2005 (project: L'Action plan UE sulla corporate governance: un'analisi giuridico-economica delle principali problematiche) is gratefully acknowledged. We thank one anonymous referee, Ike Mathur (the editor), Massimo Belcredi, Lorenzo Caprio, Francois Degeorge, Gianfranco Forte, Martin Holmen, David Pompilio, Urs Waechli, seminar participants at the University of Milan - Bicocca, and participants at the FMA 2007 European Meeting and EFMA 2007 Meeting for their helpful comments. 


\title{
Minority Shareholders' Wealth Effects and Stock Market Development: Evidence from Increase-in-Ownership M\&As
}

This Version: July 2009

\begin{abstract}
This paper examines, using a global M\&A data set, the relationship between the target firm's minority shareholders' returns and a country's stock market development in deals in which large shareholders increase their ownership stakes. For the purpose of this study, we use two measures of stock market development: (1) turnover over GDP, and (2) turnover over market capitalization. We provide evidence supporting the view that minority shareholders in target firms gain significantly more in countries with high stock market development than their counterparts in less-developed markets. Our results are robust to several firm and deal characteristics and provide evidence to policy makers that the degree of stock market development is a key determinant in improving minority shareholders' welfare.
\end{abstract}

JEL classification code: G34

Keywords: minority shareholders; stock market development; increase-in-ownership mergers and acquisitions; target returns 


\section{Introduction}

Several studies have provided evidence that the positive reaction of the target firm's stock price to a takeover announcement is a global phenomenon. ${ }^{1}$ Recent evidence also documents that large shareholders are very common worldwide, especially in countries with relatively less-developed stock markets (La Porta, Lopez-deSilanes, and Sheifler, 1999; Faccio and Lang, 2002; Claessens,, Djankov, and Lang, 2000). While acquirers usually own no or very few shares in target firms before the acquisition announcement (Betton, Eckbo, and Thorburn, 2009), there are cases in which the acquirer not only owns a sizable stake in the target firm but is the firm's controlling shareholder (Bae, Kang, and Kim, 2002; Bigelli and Mengoli, 2004; Holmen and Knopf, 2004; Buysschaert, Deloof, and Jegers, 2004). Bates, Lemmon and Linck (2006) find that minority shareholders are still able to exercise significant bargaining power and obtain a decent return in U.S. freeze-out bids, even if there is no change of control at stake. ${ }^{2}$ However, this cannot be ruled as a universal phenomenon given the different degree of countries' stock market development (La Porta, Lopez-de-Silanes, Shleifer, and Vishny, 1997). Hence, in this paper, we examine the relationship between the target firm's minority shareholders' returns and stock market development in deals in which controlling shareholders increase their ownership stakes.

To examine the gains earned by minority shareholders across the world, we focus on merger and acquisition (M\&A) deals in which controlling shareholders acquire

\footnotetext{
${ }^{1}$ For the U.S. market, see for example Andrade, Mitchell, and Stafford, 2001; Weston, Mitchell, and Mulherin, 2004; and Bruner, 2004. Andrade et al. (2001) report an average target reaction of $13 \%$ for stock acquisitions and $20.1 \%$ for cash acquisitions in the event window $(-1,+1)$ surrounding the acquisition announcement. European evidence is provided by Martynova and Renneboog (2006), who find an average market reaction of $12.28 \%$ for target firms in the event window $(-1,+1)$.

2 Bates, Lemon, and Linck (2006) report an average announcement period excess return of $14.9 \%$ for U.S. freeze-out bids.
} 
all or some of the remaining minority shareholdings in listed companies they already control. Throughout the paper, we define these deals as increase-in-ownership transactions. In contrast to acquisition proposals made by unrelated parties, target minority investors in increase-in-ownership M\&As are less likely to be endangered by entrenched managers willing to fight off offers (Shleifer and Vishny, 1989), but they are clearly at a disadvantage against a bidder who already controls the company (Shleifer and Vishny, 1997).

Controlling shareholders often claim that their increase-in-ownership transactions are necessary to restructure their individual portfolios or business groups and that such deals are value-increasing projects. Even if the bidder already controls the target firm, it often needs greater or even full control to exploit synergies and reduce costs. $^{3}$ For example, in increase-in-ownership deals aimed at delisting target firms, the delisting of the target permits the controlling firm to save on the cost of compliance with the securities laws (Carney, 2006). ${ }^{4}$ Moreover, many controlling shareholders believe that dealing with minority shareholders may prevent their companies from quickly responding to competitive pressures. ${ }^{5}$ Large shareholders sometimes increase

\footnotetext{
${ }^{3}$ For example, Sandvik AB (Sweden) claimed that owning (at least) a $75 \%$ stake in Sandvik Asia (India) was "necessary in order to ensure control of proprietary technology, provide flexibility of operations and enable it to comply with group philosophy" (AFX News, November $25^{\text {th }}, 1997$ ). The acquisition of the remaining $50 \%$ of Internet Auction Co. Ltd. (Korea) by Ebay, Inc. (U.S.A.) was explained as follows: "it wants to buy the rest of the Korean company to more strongly align ownership and management and to boost operational flexibility in the Korean marketplace" (Daily Deal, November $25^{\text {th }}, 2003$ ). Scott Greenberg, National Patent's chief financial officer, commented on the acquisition of General Physics that "by owning 100 percent, it will allow us to throw more resources behind the company" (The Washington Post, September $\left.26^{\text {th }}, 1996\right)$.

${ }^{4}$ The effects of higher costs of being public have been analyzed in great detail in the U.S. following the introduction of the Sarbanes-Oxley Act in 2002 (see, for example, Litvak, 2007; Leuz, 2007; Zhang, 2007; Leuz, Triantis, and Wang, 2008; Marosi and Massoud, 2008). See also the recent literature on goingprivate transactions (Bharath and Dittmar, 2009).

${ }^{5}$ Just to give a few examples in which competitive pressure was cited among the reasons for completing the deal (acquirer in parenthesis): Eaux des mineral de Vittel (Nestle') in 1991; Comau (Fiat) in 1999;
} 
their ownership stake to prevent block creation by other shareholders, who may be hostile (Jenkinson and Ljungqvist, 2001; Croci, 2007). Finally, there could be cases in which minority shareholders, lacking a liquid market in which to trade their shares, ${ }^{6}$ demand and put pressure on the large shareholders to buy them out. ${ }^{7}$

Using an exhaustive sample of 1,174 increase-in-ownership acquisitions across 46 countries over the period 1989-2005, we provide evidence that increase-inownership transactions do create considerable value for target shareholders. Consistent with Bates et al. (2006), minority shareholders in target firms earn an average announcement excess return of $11.95 \%$ in the five-day period around the acquisition announcement $(-2,+2)$. However, when we partition the sample at the country level, we find a significant variation in the abnormal returns around the acquisition announcement. Thus, these deals provide an ideal testing ground for exploring the reasons why minority shareholders obtain a relatively larger premium.

Previous literature suggests that a different degree of investor protection may be the reason for these differences in bidders' behavior when they already control the target firm. The legal approach to corporate governance proposed by La Porta et al.

Electrabel (Suez) in 2005; Nitto Chemical Industry Co. Ltd. (Mitsubishi Rayon Co. Ltd.) in 1997; Acer Computer Intl. (Acer Inc.) in 1999; Magellan Petro Australia Ltd. (Magellan Petroleum Ltd.) in 2005. In the Nitto case, for example, it was reported that the two firms "hope that by putting together their technological and human resources, they will be able to increase their overall competitiveness" (Jiji Press Ticker Service, 22 December 1997).

${ }^{6}$ Lack of liquidity was the main reason leading to the acquisition of the remaining outstanding shares in Ogden Projects by Ogden Corp. in 1994. R. Richard Ablon, President \& Chief Executive Officer of Ogden, said, "It has become increasingly apparent that the limited public float in shares of OPI common stock make this security less and less attractive to the investing public. It has been and continues to be difficult to develop a broad investor base for OPI common stock, particularly since Ogden has no intention of reducing its current ownership interest. We believe that the proposed transaction is an effective way to merge the two companies (Business Wire, 6 June 1994).

7 Minority shareholders' pressure was the driving factor that lead to the buyouts of minorities in Cie d'Investissement de Paris (France) by BNP, a French bank, in May 1995, and in Rhin et Moselle Assurance, a French company, by a subsidiary of Allianz SE (Germany) in November 1996. 
$(1997,1998)$ emphasizes the role played by the legal system, including both laws and their enforcement, in protecting outside investors (La Porta et al., 2000). La Porta et al. (1997, 1998, 2000) also report that protection of outside investors is positively correlated with stock market development and find that common-law countries have both the strongest protection for outside investors and the most developed markets. Though investor protection and stock market development are closely related, the latter captures issues beyond investor protection. Rajan and Zingales (2003) argue that investor protection alone cannot explain the reversals in a country's financial development and the fact that stock market development indicators are time-varying. In their view, the strength of political forces in favor of financial development plays a key role in developing strong financial markets, and the country's financial development is the outcome of ideology and the economic interests of voters and pressure groups (Aganin and Volpin, 2005). Indeed, Rajan and Zingales (2003) argue that the stock market can be either fostered or hampered by government action, depending upon the balance of powers between pressure groups.

Another important side of stock market development not fully captured by investor protection is market openness. Rajan and Zingales (2003) also discuss the role of a country's openness to trade and capital flows in promoting financial development. However, such promotion can be done without conceding too much power to minority investors. In fact, Aganin and Volpin (2005) provide the example of Italy, where openness is not associated with investor protection - while Italy has been a relatively open market, its investor protection is poor (La Porta et al., 1997; Djankov, La Porta, Lopes-de-Silanes, and Shleifer, 2008). Along these lines, Pagano and Volpin (2001) and 
Biais and Perotti (2002) argue that state intervention in the economy should be negatively correlated with financial development because the state acts as a substitute for financial markets. Finally, Guiso, Sapienza, and Zingales (2008) argue that trust affects participation in the stock market, and thus its development.

Generally, in countries with well-developed stock markets, a significant fraction of the country's population owns stock (Pagano and Volpin, 2006). Larger participation of investors in firms' equity serves as a guarantee of exposure to the media in cases of outrageous expropriations by controlling shareholders. In fact, as documented by Miller (2006), the press tends to cover firms that will be of interest to many readers. This is certainly not the case in countries with less-developed markets, where violations often go unnoticed, barring active lobbying by foreign funds in the international press (Dyck, Volchkova, and Zingales, 2008). Given these considerations, we argue that stock market development, which summarizes and incorporates the impacts of the determinants mentioned above, is an important driving force of the returns realized by target shareholders around increase-in-ownership acquisitions. This effect captures sides beyond investor protection.

In this paper, we employ two measures of stock market development used in the financial and economic development literature (Levine and Zervos, 1998) to test its impact on the abnormal return earned by target shareholders around increase-inownership acquisition announcements: (1) turnover over GDP, and (2) turnover over market capitalization. These two measures capture trading activity, or to put it differently, actual participation in the stock market. For the purpose of this study, they are both superior to the ratio between stock market capitalization and the country's 
GDP for two main reasons. First, market capitalization includes the value of the large shareholder's blocks that in general trade infrequently, particularly when they are owned by families, individuals or states (Holderness and Sheehan, 1988; Klasa, 2007; Allen, Qian, and Qian, 2005)..$^{8}$ These blocks represent a large proportion of a country's market capitalization, especially outside of the U.S. (La Porta et al., 1999; Faccio and Lang, 2002; Claessens et al., 2000). Second, as argued by Rajan and Zingales (2003), a disadvantage of stock market capitalization is that it can be affected by large increases in the value of a few companies even if few people are trading and few firms are raising equity in this market.

We find that target minority shareholders gain significantly more in developed markets than in less financially developed countries. The return differential ranges from $4.75 \%$ to $10.38 \%$ and is statistically significant for the two proxies of stock market development. The multivariate analysis confirms this result and provides further evidence of the strongly significant positive relationship between target shareholders' returns and the country's stock market development. The results are robust after controlling for several deal- and firm-specific characteristics as well as different event windows. $^{9}$

This paper makes several contributions to the literature. First, it provides evidence of the strong positive relationship between stock market development and

\footnotetext{
${ }^{8}$ Holderness and Sheehan (1988) compare the likelihood of a control change between firms that are majority-owned by families and those majority-owned by corporations. They find that firms in which the majority shareholder was an individual investor (or family) were less likely to be acquired. Klasa (2007) finds only 84 observations for the sale of the family's controlling stake in the U.S. over a long period (1984-1998).

${ }^{9}$ More specifically, we also employ more extended windows -i.e., $11(-5,+5)$ and $21(-10,+10)$ days, respectively, surrounding the acquisition announcement day to allow information about the transaction to be leaked in advance or be incorporated slowly into the stock prices. This issue is particularly relevant in countries with inefficient equity markets.
} 
target-firm minority shareholders' wealth effects. This indicates that an active and more developed stock market favors minority shareholders, as reflected in the significant gains earned around the acquisition announcement even in transactions with no change of control. Second, it carries out the first worldwide analysis of increase-in-ownership M\&A deals, thus illustrating the cross-country determinants of target returns. Finally, the evidence that minority shareholders benefit from developed stock markets has useful implications for policymakers and shows the importance of a developed stock market in disciplining the behavior of large shareholders.

The remainder of the paper is structured as follows. Section 2 presents the measures of stock market development, the data, and sample characteristics. Section 3 reports the results of the empirical analysis, and Section 4 discusses the forms of the deals and the underlying motivations. Section 5 discusses and presents robustness tests. Finally, Section 6 provides the conclusions.

\section{Data and Methodology}

\subsection{Measures of Stock Market Development}

To measure stock market development and examine its relationship with target minority shareholders' returns, we employ two proxies of market liquidity. Following Levine and Zervos (1998), we use: (1) turnover over GDP, which is the value of the trades of domestic equities on domestic exchanges over GDP; and (2) turnover over domestic market capitalization, which is the value of the trades of domestic equities on domestic exchanges relative to the size of the market. 
While market capitalization has often been used as a measure of stock market development, this variable has several shortcomings. In particular, by definition, market capitalization includes the value of the controlling shareholder's blocks, which trade infrequently (Holderness and Sheehan, 1988; Klasa, 2007; Allen, Litov, and Mei, 2006) and can represent a large proportion of a country's market capitalization given that, outside the U.S., large shareholders are common (La Porta et al., 1999; Faccio and Lang, 2002; Claessens et al., 2000). Rajan and Zingales (2003) highlight another drawback of stock market capitalization. This variable merely measures the amount of equity listed in the stock market. Hence, large increases in value of few companies can have a substantial impact on this measure even if few individuals are trading and few firms are raising equity in this market. In addition, as Levine and Zervos (1998) and Rajan and Zingales (2003) argue, a large stock market is not necessarily liquid, and if it is not, it can fail to capture important aspects of stock market development.

Hence, turnover-based measures serve as better proxies than stock market capitalization over GDP. In fact, given that controlling blocks trade infrequently, turnover is affected relatively less by the holdings of controlling shareholders. ${ }^{10}$ However, in order to control for the influence of the price effect (Levine and Zervos, $1998)^{11}$ and the relative size of financial markets with respect to the country's GDP, we

\footnotetext{
${ }^{10}$ The difference between the two measures can be explained by comparing two hypothetical countries. In each of these countries, one company is listed on the local stock exchange. In the first country, the local firm has a large shareholder who owns $80 \%$ of its shares, and in the second country the corporation's ownership is diffused with no large shareholder. While the market capitalization of the two companies could be the same, barring a sale of the company in country two, the dollar value of the turnover would be much higher in the second country. In all likelihood, few shares will be traded in the first country.

11 If markets anticipate future events, it is likely that stock prices will increase, raising the value of stock transactions and therefore the turnover value. The price effect influences both turnover and stock market capitalization.
} 
also include the ratio between market capitalization and the country's GDP in the regression analysis.

\subsection{Data and Sample Characteristics}

The original sample comprises all acquisitions of public target firms reported in Thomson Financial Securities Data's Thomson ONE Banker during the period January 1989 to December 2005. Our sample period begins in 1989 because our main variables at the country level have sufficient coverage in the World Development Indicators database only after 1989.

We consider the completed acquisitions of more than $5 \%$ of the target's equity that took place in 59 countries (listed in Table 1$)^{12}$ with deal values of at least $\$ 1$ million in which the acquirer owns at least $30 \%$ of the target firm's capital after the transaction. Thirty percent of a company's equity is generally a large-enough fraction to exercise control. In fact, in many takeover laws, more notably the U.K. Takeover Code, a shareholder who exceeds $30 \%$ of a company's equity has to make a public offer for all the outstanding shares of the company. ${ }^{13}$ Thus, the $30 \%$ threshold is applied by many legislators to guarantee effective control to one party to the detriment of minority shareholders. For the above reasons, the $30 \%$ threshold is preferred to $20 \%$, a usual cutoff point in the ownership structure literature to identify controlling shareholders (La Porta et al., 1999; Faccio and Lang, 2002), and to 50\%, the percentage of shares that

\footnotetext{
12 A $60^{\text {th }}$ country, Taiwan, was dropped due to missing data in the World Development Indicators database.

13 The "Report on the implementation of the Directive on Takeover Bids," a European Commission publication in February 2007, reports that the acquisition of a $30 \%$ stake (or $1 / 3$ ) is a condition triggering a mandatory bid in 18 out of the 25 EU countries listed (see Appendix B in the Report). In one country, Slovenia, the threshold is even lower (25\%). The largest European countries, like Germany, Italy, France, and the U.K., have a $30 \%$ (or $33.33 \%$ ) threshold.
} 
assure the shareholder the (simple) majority in any company's vote. ${ }^{14}$ After this first step, the original sample is reduced to 18,213 deals that satisfy these requirements.

The second step consists of the identification of increase-in-ownership transactions. The Thomson ONE Banker M\&A database provides the names of ultimate owners for targets and acquirers. So, we initially rely on these two items to include in the sample all deals in which Thomson ONE Banker reports that both the target and the acquirer are controlled by the same firm/individual investor. As a result, 2,471 deals satisfy this requirement.

However, since Thomson ONE Banker often reports the post-acquisition parent company of the target firm and not the pre-acquisition parent company, we manually searched information about these deals in articles available in Lexis/Nexis to confirm that the bidder (or a firm belonging to the acquirer's group) is actually the ultimate owner of the target before the deal takes place. We also verified that these deals are new transactions and not just follow-ups of previous deals. ${ }^{15}$ We removed 937 false increase-in-ownership transactions with this manual search, without which we would have overestimated the number of increase-in-ownership acquisitions. Finally, we also excluded deals in which the stake held by the acquirers before the announcement was greater than $90 \%$ (75 cases), in order to eliminate squeeze-out bids. In squeeze-out bids, the minimum price is often determined by law, especially in European countries, and the free-float is small. A small free-float increases the price effects of trades (Chan,

\footnotetext{
${ }^{14}$ Our results are robust to cut-offs other than $30 \%$. For example, we obtain similar results when we use either $50 \%$ or $75 \%$ cut-off points.

${ }^{15}$ For example, if firm $\mathrm{X}$ acquires $70 \%$ of the target equity in March and then launches a tender offer in April for the remaining 30\%, we do not include the tender offer in our sample. Deals of this type are required by law in many countries (mandatory bid rule). These deals are also not likely to generate any reaction at the time of the announcement because they are fully anticipated.
} 
Chan, and Fong, 2004) and makes float manipulation easier (Allen, Litov, and Mei, 2006;

Greenwood, 2009). After these criteria, our sample is composed of 1,459 firms.

Finally, we verified whether target firms in the remaining 1,459 transactions have stock price data available on Datastream, which led to the loss of 285 firms. The final sample, which is used in the empirical analysis, includes 1,174 increase-inownership deals in 46 countries. ${ }^{16}$ We summarize the steps that led to the final sample in Table 1.

[Please include Table 1 about here]

We present and describe all of the country-level, firm-level, and deal-specific variables used in the empirical analysis in Table 2 . All variable definitions are listed in the Appendix. As expected, our two proxies for stock market development exhibit great variability, varying from values below $2 \%$ to values of over $200 \%$ for turnover over GDP and turnover over market capitalization, respectively. Other variables that relate to development are: the stock market capitalization over GDP, and private credit, computed as in Djankov, McLeish, and Shleifer (2007). ${ }^{17}$ In contrast to the other measures, which are mainly related to the equity markets, private credit is a proxy that captures the development of the financial system at large. We also include in the analysis variables that measure economic development (Levine and Zervos, 1998): the log of the per-capita GDP, which controls for differences in wealth between countries;

\footnotetext{
${ }^{16}$ There are 403 transactions from Europe, including 25 from the former Soviet bloc, 328 from Asia, 77 from Australia and New Zealand, 25 from South Africa, and 341 from the Americas, of which 207 are from the United States.

${ }^{17}$ This is the ratio of credit from deposit-taking financial institutions to the private sector (IFS lines $22 \mathrm{~d}$ and 42d) to GDP (IFS line 99b), expressed as a percentage, for the year before the transactions. (IFS is the International Monetary Fund's (IMF) International Financial Statistics.)
} 
and the annual GDP growth, to control for the country's economic condition. Table 2 reports descriptive statistics for all these variables.

We also examine the country's legal origin as a proxy for the quality of the legal system, as widely used in the law \& finance literature (La Porta et al., 1997, 1998). Another measure used to assess the degree of investor (shareholder) protection is the anti-director-rights index (ADRI), fist proposed by La Porta et al. (1997). In the empirical analysis, we use the revised ADRI as computed by Djankov et al. (2008) (DLLS Index) to measure shareholder protection. ${ }^{18}$ Table 2 also documents that almost half of the observations (47\%) comes from countries of Common law tradition, which probably explains the high mean value of the investor protection index (DLLS equals 3.55). Finally, we use the percentage of households who own television sets to control for the impact of media pressure, following Dyck and Zingales (2004), who find that media pressure is a dominating factor in curbing private benefits and thus may affect the price offered to the targets' shareholders. ${ }^{19}$ As reported in Table 2, the percentage of households owning television sets is relatively high in our sample.

Regarding firm-level variables, we also include size, which is defined as the log of the firm's market value of equity at the end of the year before the deal; ROA, which is the return on assets in the year before the deal; market-to-book (M/B), which is the ratio of the market value of equity in US\$ divided by the common equity in US\$ at the end of the year before the deal; stock-price performance during the year before the

\footnotetext{
${ }^{18}$ Note that these indices are based on information collected at a given point in time-i.e., the mid-1990s for La Porta et al. (1997), and recent years for Spamann (2006) and Djankov et al. (2008). Thus, there are cases in which the value of these indexes includes changes that took place after some of the deals. Unfortunately, there is no time series of any anti-director-rights index.

${ }^{19}$ We select television over daily newspaper diffusion because the time series of the daily newspaper diffusion is incomplete and only values for the period 1997-2000 are available.
} 
deal; and leverage, which is the ratio of the book value of financial debt as a percentage of the book value of total assets at the end of the year before the deal. We also include: cash holdings; which is the ratio of cash plus tradable securities over total assets at the end of the year before the deal; collateral, which is defined as the ratio of tangible assets to total assets at the end of the year before the deal; and the percentage of the target's equity held by the bidder before the transaction.

The median target market capitalization is U.S. \$221 m. The acquiring firm owns, on average, more than $60 \%$ of the target firm's equity before the deal (median equals $62.9 \%$ ) and increases its stake to $93 \%$ (median equals 100\%) when the deal is completed. A considerable number of deals end with the bidder taking the target private $(80.23 \%)$. Target firms do not exhibit good operating performance, with a median ROA of $3.94 \%$, and their median stock-price performance in the year preceding the acquisition is $0 \%$. Median market-to-book ratio of target firms is equal to 1.38 . Further, targets hold, on average, a similar percentage of cash and debt.

We also collect data about the most recent ownership structure of the bidding company before the acquisition announcement to identify the type of its controlling shareholder. We identify the ownership structure and the type of the controlling shareholder from a variety of sources, including the Claessens et al. (2000) and the Faccio and Lang (2002) databases, ${ }^{20}$ Worldscope, Lexis/Nexis, and companies' Web sites. In this way, we obtain data about the type of controlling shareholders for 1,100 out of the 1,174 bidders. ${ }^{21}$ Bidders are classified into eight categories on the basis of the type

\footnotetext{
${ }^{20}$ Both the Claessens et al. (2000) and the Faccio and Lang (2002) databases are publicly available on the Journal of Financial Economics Web site.

${ }^{21}$ We follow Claessens et al. (2000) and Faccio and Lang (2002) in defining ultimate owners.
} 
of their ultimate owner: family firm (463), state-owned firm (120), widely held firm (231), widely held financial institution (46), financial institution (125), those controlled by a widely held firm (52), those controlled by a widely held financial institution (42), and miscellaneous (the largest shareholders are the employees, foundations, etc.) (21).

Finally, Table 2 also presents deal-specific variables. The first deal-specific variable is the pre-acquisition run-up, computed from 42 days to 3 days before the start of the event window, similar to Bates et al. (2006). ${ }^{22}$ Contrary to the literature (Schwert, 1996; Betton, Eckbo, and Thorburn, 2009), firms in our sample do not exhibit a substantial run-up in the period immediately before the acquisition. The average (median) run-up is $3.88 \%(2.6 \%)$. We also include a variable for the method of payment (cash). Cash deals usually exhibit larger reactions for both target and bidding firms than do stock-financed transactions (Huang and Walkling, 1987; Travlos, 1987; Faccio and Masulis, 2005). We define as a cash (stock) deal a transaction in which at least $80 \%$ of the deal value is paid in cash (stock). In our sample, there are 772 cash deals (66\%) and 358 stock deals. $^{23}$ We also include dummy variables to control for industry diversification (Morck, Shleifer, and Vishny, 1990), domestic deals (Rossi and Volpin, 2004), and deals aimed at delisting the target firm. When the bidder wants to take the target company private, it needs all of the target's minority shareholders to accept its offer or, at least, it needs enough shares to force a squeeze-out bid. Thus, the premium offered should be higher, leading to larger abnormal returns. Target firms share the same industry (two-digit SIC codes) with the acquiring firms in $48.29 \%$ of the sample

\footnotetext{
${ }^{22}$ We use this definition of run-up with CARs in the event window $[-2,+2]$. As a general definition, we compute run-ups from 42 days to the day before the beginning of the event window being considered.

${ }^{23}$ The remaining 44 deals are deals with mixed forms of payment-i.e., neither cash nor stock reaches $80 \%$ of the deal value.
} 
observations (567 out of 1,174). Domestic deals represent the vast majority of the increase-in-ownership deals (72\%). Deals aimed at taking the target private are more than $80 \%$ of the sample.

Almost $65 \%$ (238 out of 1,058) of the deals are carried out with a tender offer based on the information collected from Lexis/Nexis. ${ }^{24}$ Only 238 out of the 1,058 (22.5\%) of transactions are merger deals. While mergers and tender offers are the most common forms of increase-in-ownership deals, these deals can take other forms. In fact, the controlling shareholder may increase its ownership stake by buying out another block holder in the company (block purchases). Finally, the controlling shareholder may increase its stake by purchasing shares in the open market without launching a tender offer for the target's share (open-market transactions). However, the roles of block purchases (10\%) and, especially, open-market transactions $(1.23 \%)$ is of residual importance. Table 3 presents the pair-wise correlations between the stock market development, economic development, and media pressure variables, respectively.

[Insert Table 2 about here]

[Insert Table 3 about here]

We conduct a preliminary event-study analysis to evaluate firms' stock price reactions to the announcement of an increase-in-ownership acquisition, and we estimate the market model using daily returns to adjust for systematic risk (Table 4). ${ }^{25}$ The market reaction for target firms is positive and statistically significant, with an average cumulative abnormal return (CAR) of $11.95 \%$ in the five-day $(-2,+2)$ interval

\footnotetext{
${ }^{24}$ Note that we do not use the form of the deal reported by Thomson ONE Banker because, after comparison with newspaper articles on Lexis/Nexis, we found that the item was to an extent unreliable.

${ }^{25}$ The estimation period is a 200-day interval from day -240 to day -41 with respect to the event day.
} 
surrounding the acquisition announcement. The average CAR is $13.28 \%$ in the event window $(-5,+5)$ and $14.51 \%$ in the event window $(-10,+10)$. The average return in increase-in-ownership transactions is lower than the return for M\&A announcements that lead to a change of control, which is around $16 \%$ in the U.S. (Andrade et al., 2001) and about $12.28 \%$ in Europe (Martynova and Renneboog, 2006). ${ }^{26}$ However, the magnitude of the targets' reactions in increase-in-ownership acquisitions is still economically significant. Hence, even though such transactions do not result in a control change, shareholders of target firms gain a considerable abnormal return. This positive and significant increase conflicts with the view that increase-in-ownership transactions are merely designed to take advantage of the target's minority shareholders.

[Insert Table 4 about here]

Table 4 also breaks down the sample according to the target firm's country. While the mean and median of the full sample are positive and significant over the 5day announcement period, looking at the CARs at the country level immediately reveals that large differences exist between countries. Average CARs in the $(-2,+2)$ interval go from a minimum of $-28.99 \%$ in Russia (only one observation) to a maximum of $29.60 \%$ in neighboring Latvia (again, only one observation). ${ }^{27}$ While these extreme values may be due to the limited number of observations available for some countries, cross-country variations are also seen in countries with more observations such as France, Germany, and the United Kingdom (2.31\%, 7.71\%, and 26.03\%, respectively).

\footnotetext{
${ }^{26}$ This result $(12.28 \%)$ refers to the event window $(-1,+1)$. The CAR in the $(-1,+1)$ event window is $10.57 \%$ in our sample. Abnormal returns are $14.73 \%$ in the event window $(-5,+5)$ in Martynova and Renneboog (2006), very close to our estimate.

27 Honk Kong has the highest average CAR (about 33\%) in the event windows $(-5,+5)$ and $(-10,+10)$. Russia has the lowest CAR in all the event windows.
} 
The cross-country dispersion of returns raises the issue of whether characteristics at the country level can explain the magnitude of these differences. In the next section, we focus on stock market development and test, using both univariate and multivariate analyses, whether it plays a significant role in explaining target minority shareholders' returns. We will first compute the CARs enjoyed by targets. Previous literature has documented that deal and firm characteristics also have a significant impact on abnormal returns around acquisition announcements; hence, these factors will be considered along with the proxies of stock market development in the multivariate cross-sectional regressions analysis.

\section{Empirical Analysis}

\subsection{Univariate Results}

Table 5 tests the relationship between target returns and stock market development. We divide our sample by stock market development based on the measures discussed above and examine in a univariate type of analysis the returns of targets in developed versus undeveloped markets. In Panel A of Table 4, we use turnover over GDP and turnover over market capitalization as measures of stock market development. Targets are ranked in descending order for each of the two stock market development proxies and divided into four groups of equal size. Targets belonging to the bottom (top) quartile are considered as the low- (high-) development targets. Targets belonging to quartiles two and three are categorized as median. While target shareholders experience positive abnormal returns in the overall sample $(11.95 \%)$, we find that they gain $17.50 \%$ in high-development markets as compared with $7.12 \%$ in 
low-development markets during the 5 days around the acquisition announcement. Their mean difference is $10.38 \%$ and it is strongly significant at the $1 \%$ significance level, which highlights the importance of stock market development in driving target returns.

When we employ the turnover over market capitalization as a proxy of stock market development, the results are similar to those obtained using turnover over GDP: targets in developed markets earn a 5 -day CAR of $14.25 \%$ as compared with $9.50 \%$ in less-developed markets. Their mean return difference $(4.75 \%)$ is again statistically significant, which strongly corroborates the view that stock market development is a significant driving force of target returns. Our results are consistent when we use the event windows $(-5,+5)$ and $(-10,+10)$.

[Insert Table 5 about here]

\subsection{Multivariate Results}

The event-study analysis shows that the reaction to the announcement of an increase-in-ownership deal differs across countries, and the findings in the univariate tests signify the importance of the level of the country's stock market development in shaping the target's returns. To better examine the impact of stock market development on targets' performance around acquisition announcements, we adopt a multiple regression framework, in which we employ stock market development measures and various country, target and deal characteristic controls as independent variables.

CARs are regressed against country-level variables to determine whether these variables affect the premiums offered to minority shareholders. Table 6 reports the results of these regressions using CAR in three different event windows $-(-2,+2),(-5$, $+5)$, and $(-10,+10)$ - to take into account the different efficiency of the stock markets to 
incorporate information. ${ }^{28}$ In all regressions, we report the results of the two stock market development variables along with all other financial and economic development control variables. The turnover over GDP positively affects the targets' abnormal returns, as the coefficient carries a positive sign and is highly significant at the $1 \%$ level. The effect of turnover over GDP is also economically significant: a change of onestandard-deviation in turnover over GDP produces an increase of 3.96\% in the abnormal returns around acquisition announcements in Column (1), of 3.90\% in Column (2), and of $3.76 \%$ in Column (3). The positive coefficient indicates that a larger and more active stock market leads to higher returns enjoyed by minority shareholders. In fact, active markets signal, first, that people actually invest and participate in the stock market, directly and indirectly, and second, that market participants are able to react quickly to new information. Thus, they are more likely to punish controlling shareholders who try to underpay minority investors (La Porta et al., 2000).

The same results are obtained for the other proxy of stock market development, turnover over market capitalization. In regressions (2), (4), and (6), the coefficient that represents stock market development is positive and significant. Moreover, for this variable, the impact is economically relevant: a change of one standard deviation in turnover over market capitalization increases the CAR by $2.11 \%, 1.87 \%$, and $1.93 \%$, in the event windows $(-2,+2),(-5,+5),(-10,+10)$, respectively. The coefficient for English legal origin, the proxy for the quality of the legal protection between investors among countries (La Porta et al., 1998), is also positive and highly significant. In contrast to the proxies for stock market development, the private credit variable is insignificant. The

\footnotetext{
${ }^{28}$ In Tables 6 through 11, robust standard errors are adjusted for clustering at the country level. Time effects are also included in all regressions.
} 
economic variables and shareholder protection, represented by the DLLS index variable, are generally insignificant for all measures of stock market development. On the other hand, media pressure has a negative and significant coefficient in longer event windows when turnover over GDP is used as proxy for stock market development (in Columns 3 and 5). This result is surprising because it is more likely to expect a positive relationship between people's access to news and the loss of reputation due to an attempt to expropriate minority shareholders with a low offer as in Dyck et al. (2008). However, the media variable is not significant in regressions using the other proxy for stock market development (turnover over market capitalization, in Columns 4 and 6).

[Insert Table 6 about here]

We include the firm and deal characteristics discussed in Section 2.2, along with stock market development indicators, in the regressions of Tables 7, 8, and 9. In these regressions, we control whether the relationship between target returns and stock market development is driven by correlation with some of the various deal- and firmspecific factors suggested by the related literature. Consistent with the results in Table 6 , the coefficients that represent stock market development are positive and strongly significant in Table 7. More specifically, the coefficient of Turnover/GDP carries a positive sign and is significant at the $1 \%$ level, while Turnover/Market Capitalization carries a coefficient of 0.0383 and is significant at the $5 \%$ level. A change in one standard deviation in the two proxies of stock market development produces economically significant increases in the market reaction around the acquisition announcement. More specifically, a one-standard-deviation increase in Turnover/GDP raises abnormal returns 
by $3.70 \%$ in Column (1), while the same change in Turnover/Market Capitalization increases abnormal return by slightly less than $2 \%(1.92 \%)$.

The English origin coefficient is also positive (0.0657) and strongly significant. Among firm characteristics, the DLLS index and the stock-price performance variable in the year preceding the increase-in-ownership acquisition have a significantly positive relationship with target returns in all regressions. A good stock-price performance in the year before the acquisition decreases the abnormal return, a result that is consistent with the fact that increase-in-ownership deals are more valuable for minority shareholders in poorly performing companies. ${ }^{29}$ Moreover, when the company is performing well, the stock price level is relatively high, and so there is less room for large premiums. Further, consistent with the literature, the market prefers cash deals to stock deals because a cash payment eliminates the uncertainty about the offer value. In addition, the market reaction is stronger when the motivation of the deal aims at delisting the target firm. Consistent with Bris and Cabolis (2008) and Rossi and Volpin (2004), domestic deals exhibit a significantly negative relationship with target returns. Finally, the main results for stock market development variables for the event windows $(-5,5)$ and $(-10,10)$ are confirmed. The magnitude of the coefficients is similar to the ones in 5-day CAR regressions, which also assures the economic significance of the variables. $^{30}$

\section{[Insert Table 7 about here]}

\footnotetext{
${ }^{29}$ In unreported analysis, we also run the same set of regressions, removing either the stock price performance in the previous year or the target run-up CARs. In fact, for some observations these variables may partially overlap. We find that when we include just one of these two variables the results are qualitatively similar to those presented in Table 6.

${ }^{30}$ A one-standard-deviation increase for Turnover/GDP in event windows $(-5,+5)$ and $(-10,+10)$ produces a change of about $4 \%$ in the abnormal returns. The change is between $1.84 \%$ and $2.31 \%$ for Turnover/Market Capitalization.
} 
We control for ownership structure effects in Table 8, including dummies for the type of controlling shareholders. La Porta et al. (1999) find that there are more family (widely held) firms in countries with poor (good) investor protection, and Faccio and Lang (2002) document that family firms are more common in continental Europe than in Ireland and the United Kingdom. Furthermore, according to the literature, families seem to value control more than corporate shareholders, either because they value the opportunities to consume perquisites more than corporate majority shareholders (Demsetz and Lehn, 1985) or because some benefits of control, such as the pride of running the company they, or a family member, founded, cannot be transferred (Holderness and Sheehan, 1988). Hence, it may be possible that the lower announcement returns for targets in some countries are driven by differences in the type of controlling shareholder.

The results remain consistent as both stock market development variables are positive and strongly significant when the ownership structure control variables are added. For the regression in column (1), a one-standard-deviation increase in Turnover/GDP raises abnormal returns by $3.75 \%$, while the same change in Turnover/Market Capitalization increases abnormal return by $1.84 \%$ in Column (2). Among the ownership structure variables, the dummies for bidders controlled by widely held firms or widely held financial institutions, and when the controlling shareholder of the bidding firm is a foundation or employees, exhibit a significantly negative relationship with target returns in the majority of the regressions. While the negative coefficient for bidders whose controlling shareholder is a widely-held firm, a foundation, or employees, can be attributed to large shareholders' monitoring of managers (Shleifer 
and Vishny, 1997), it is not clear why widely held financial institutions offer lower premiums. Consistent with industrial widely held firms, these corporations do not have large shareholders. Thus, monitoring by a large shareholder cannot explain this result. The results are consistent when the two other alternative windows are employed.

$$
\text { [Insert Table } 8 \text { about here] }
$$

Overall, multivariate cross-sectional regressions strongly indicate that developed stock markets are a key determinant of the target firm's announcement returns. The empirical evidence suggests that targets' minority investors reap greater benefits in terms of market reaction in countries with developed stock markets. In other words, well-developed stock markets favor minority shareholders and enable them to extract larger gains.

\section{The Impact of Deal Form}

We have not yet considered the form of the deal. As indicated in Table 2, tender offers are the most common deal forms. The form of the deal has been documented as a major factor in determining target returns because there is more room for expropriation in mergers than in tender offers. In fact, even under U.S. (Delaware) law, tender offers made by controlling shareholders are subject to a less-demanding standard of review than negotiated mergers (Bates et al., 2006). Bae et al. (2002) documents how mergers can be used to expropriate minority shareholders in Korea. Hence, in the case of mergers, a smaller reaction for target companies is expected. The prediction for the coefficient of the block purchase dummy is negative. In fact, with a block purchase, the target firm loses a minority block holder who could have power and 
incentive to monitor the controlling shareholder. The sign of the coefficient of the openmarket purchase is more difficult to predict, and it is also affected by the timing of the purchases. To control for these effects, we run regressions by adding dummies for the deal form. ${ }^{31}$

In Table 9 we present the results of these regressions for event window $(-2,+2){ }^{32}$ Our two stock market development indicators remain constantly positive and strongly significant even when we add the variables of the deal forms. The dummy for a merger deal is negative and significant in all regressions, even when we control for the method of payment (we include the variable Cash in the regression). Thus, the coefficient confirms that mergers tend to be less favorable for target shareholders than tender offers. The same result is obtained for block and open-market transactions, which are significantly negative in the great majority of the regressions. This finding indicates that target shareholders are better off when the deal takes the form of a tender offer as expected, but stock market development still matters even after controlling for the form of the deal.

[Insert Table 9 about here]

\section{Robustness Checks}

\subsection{Regressions with Country-Fixed Effects}

\footnotetext{
${ }^{31}$ In unreported results, we also test the impact of the form of the deal in a univariate type of analysis. Consistent with the view that mergers are less beneficial for minority shareholders than tender offers, target firms' CARs for mergers are lower than CARs for tender offers $-8.36 \%$ vs. $15.34 \%$ in the event window $(-2,+2)$-and the difference is statistically significant. Abnormal returns around increase-inownership acquisitions carried out through block trades and block trades followed by a compulsory offer are even lower (6.60\%, and $5.77 \%$, respectively). The announcement of an open-market acquisition does not impact the target firm's stock price $(-0.07 \%)$, which suggests that the market does not expect any follow-up offer.

${ }^{32}$ In unreported analysis, we also find remarkably similar results for the other two event windows.
} 
By using clustered standard errors at the country level, there could be concerns due to the presence of unobservable country heterogeneity and omitted regressors. In order to alleviate these concerns, we re-run the regressions of Tables 6 and 7 using country-fixed effects in addition to clustered standard errors. From these regressions, we remove time-invariant variables, like the English Origin, and the DLLS index. We present the results in Tables 10 and 11, which confirm that the strong positive effect of a developed stock market still holds even when we include country-fixed effects.

[Insert Tables $10 \& 11$ about here]

\subsection{Deal Motivations}

Finally, we also collect data from Lexis/Nexis regarding the motivations that led to increase-in-ownership deals for 1,058 deals. We classify motivations in the following eight categories: block-holders' exits (50), controlling shareholders who prefer further control over targets (156), the desire to be able to respond to competitive pressures (87), controlling shareholders who prefer to take targets private (93), the desire to consolidate/simplify the group structure (406), targets' bad performance (147), bidders/parents' bad performance (47), synergies/efficiency gains (61), and pressure by shareholders (7). This classification relies on public information provided by newspapers and newswire articles found on Lexis/Nexis. In an unreported regression analysis, we include dummies for the deal's motivations as described above. All stock market development variables are still positive and strongly significant, while dummies for the reasons behind the deal appear to have an insignificant impact on target firm's returns. 


\subsection{Are the Bidder and Parent Companies the Same Firm?}

One of the major differences in increase-in-ownership acquisitions is related to which firm actually carries out the acquisition. Often, parent companies do not directly buy out or increase their stakes in the listed subsidiaries but instead use another firm as the acquisition vehicle. This strategy may be used to make the transaction less transparent and to transfer value to controlling shareholders (Bae et al., 2002; Faccio and Stolin, 2006). Thus, we examine whether the results differ when we control for the cases in which the parent company (as recorded by Thomson ONE Banker) makes the acquisition directly.

Parent companies are the bidding firms in 651 out of the 1,174 deals in our sample (55.45\%). Looking at the results (not reported for reasons of space), there is no significant difference for target shareholders if the parent company conducts the acquisition or not: the abnormal return is $12.53 \%$ when the bidder is the parent company and $11.23 \%$ when the bidder is not the parent company in the event window ($2,+2)$. When included in the regressions model, the coefficient for the direct acquisition is not statistically significant in all regressions, while the results for the other variables are identical to those shown in the main analysis.

\subsection{Raising Equity After Increase-in-Ownership Transactions}

The possibility that the controlling shareholders may have to raise external capital in public markets in the near future may limit the extent to which they are willing to take advantage of minority shareholders. This reputation argument, also discussed by Shleifer and Vishny (1997), is based on the fact that firms that are known for unpleasant 
treatment of minority investors may face difficulties in selling their securities to new investors. However, this threat of future punishment is only possible if a wellfunctioning stock market exists in the country.

To investigate this issue empirically, we downloaded all equity issues (including SEOs, IPOs, private placements, and convertible issues) in the period from 1989 to 2008 from the Thomson ONE Banker "Equity Issues" database. We manually controlled whether the bidding firm (and the parent firm) sold equity to the public in the 24-month (36-month) period after the increase-in-ownership acquisition. ${ }^{33}$

Overall, we have 211 (251) bidders that issued equity in the 24 (36) months following the increase-in-ownership transactions (18\% for 24 months, and $21.4 \%$ for 36 months). In unreported analysis, we find that firms targeted by issuing bidders realized an average $11.2 \%$ in the event window $(-2,+2)$. However, this abnormal return is not statistically (and economically) different from that reported for non-issuing firms in the same event window (12.13\%). Similar results are obtained for event windows $(-5,+5)$, and $(-10,+10)$. We do not observe any significant difference between the two groups using the 36-month interval. This result is not due to a possible IPOs effect. In fact, we have a very limited number of bidders that went public in the 24 (36) months after the acquisitions (7 and 10, respectively).

We also include an equity-issue dummy in the regression models of Table 7. Contrary to the reputation-based explanation, the coefficient of this variable is never statistically significant. Our main results are not affected by the inclusion of these

\footnotetext{
${ }^{33}$ While arbitrary, the length of these periods are reasonably short to assume that the large shareholders knew at the time of the acquisition that they would have to raise equity later, and long enough to give time for firms to actually make new issues.
} 
variables. Thus, the larger return realized by target shareholders in countries with developed stock markets is not related to the likelihood of raising new equity in the near future. $^{34}$

\subsection{Creditor Rights}

In an additional robustness check, we use the creditor rights index provided by Djankov, McLiesh, and Shleifer (2007) as another proxy for the quality of the legal system. The advantage of this index is that it provides time series data on creditor rights for 129 countries over the period $1978-2002 .^{35}$ In unreported regressions, we find that the creditor rights index is never statistically significant. A prominent explanation for this result could be that shareholders' interest may diverge from those of creditors, as the capital structure literature confirms. ${ }^{36}$ Thus, a higher protection for creditors may be detrimental to shareholders in general, and this effect offsets, at least partially, the improvement in the legal system. The coefficients of our proxies for market development are again strongly positive and significant in these regressions.

\subsection{Institutional Investors' Ownership}

The observed positive relationship between stock market development measures and target firm returns could be due to omitted variables. For example, in

\footnotetext{
${ }^{34}$ As an additional robustness check we also take into account the equity issues made by the parent company (as reported on Thomson ONE Banker). With this new definition, we have 249 (302) deals followed by an equity issue made by either the bidding firm or its parent company. We find that even in this case the abnormal reactions of the two groups (issuing bidders vs. non-issuing bidders) are similar. We do not report the result for the sake of brevity.

${ }^{35}$ The data are available on Andrei Shleifer's Web site. We use 2002 data for the years not covered by the Djankov, McLiesh, and Shleifer (2007) data set. The only countries without creditor rights data included in our sample are Luxembourg and Estonia.

${ }^{36}$ See for example Harris and Raviv (1991) for an excellent survey.
} 
developed stock markets, institutional investors may play an active governance role. If they are present in firms involved in the deals, they may have a higher bargaining power and therefore secure a higher compensation. Using the average institutional ownership at country level for 27 countries provided over the period 2000-2005 provided in Ferreira and Matos (2008) and Massa, Ferreira, and Matos (2009), we control for institutional investors' ownership. ${ }^{37}$ In an unreported analysis, we find that our results do not change if we include this variable in our regression models. More specifically, we find an insignificant relationship between target CARs and institutional ownership, while the coefficients of both stock market development indicators remain positive and strongly significant.

\section{Conclusions}

This paper investigates the relationship between stock market development and announcement returns to target firm's minority shareholders in increase-in-ownership acquisitions. The evidence supports the view that target firms' shareholders do not enjoy the same privileges everywhere. While on average positive, abnormal returns differ greatly across countries, and the level of stock market development appears to play a significant role in driving targets' returns.

We use a global sample of 46 countries, which includes 1,174 such deals, and we measure stock market development based on two alternative proxies: turnover over GDP and turnover over market capitalization. Our findings indicate that, when the company's controlling shareholders engage in increase-in-ownership acquisitions,

${ }^{37}$ Institutional ownership is defined as the average of total institutional ownership as a percentage of market capitalization over the period 2000-2005. 
minority shareholders greatly benefit from the country's stock market development. These results hold when we control for several deal and target characteristics and have implications for policymakers. One of the policymakers' top priorities should be to improve stock market participation and increase market liquidity-i.e., develop an efficient stock market. In fact, our results document that a developed stock market serves as an effective disciplinary mechanism even for a bidder that already controls the target company. 


\section{References}

Aganin, A., Volpin, P., 2005. The history of corporate ownership in Italy, in: Randall K. Morck (Ed.), The History of Corporate Governance Around the World. University of Chicago Press, Chicago, pp. 325-361.

Allen, F., Litov, L., Mei, J., 2006. Large investors, price manipulation, and limits to arbitrage: An anatomy of market corners. Review of Finance 10, 645-693.

Allen, F., Qian, J., Qian, M., 2005. Law, finance, and economic growth in China. Journal of Financial Economics 77, 57-116.

Andrade, G., Mitchell, M., Stafford, E., 2001. New evidence and perspective on mergers. Journal of Economic Perspectives 15, 103-120.

Bae, K.H., Kang, J.K., Kim, J.M., 2002. Tunneling or value added? Evidence from mergers by Korean business groups. Journal of Finance 57, 2695-2740.

Barath, S., and Dittmar, A., 2009. Why do firms use private equity to opt out of public markets. Review of Financial Studies, forthcoming.

Bates, T.W., Lemmon, M.L., Linck J.S., 2006. Shareholder wealth effects and bid negotiation in freeze-out deals: Are minority shareholders left out in the cold? Journal of Financial Economics 81, 681-708.

Biais, B., Perotti, E., 2002. Machiavellian privatization. American Economic Review 92-1, 240258.

Bigelli, M., Mengoli, S., 2004. Sub-optimal acquisition decision under a majority shareholder system. Journal of Management and Governance 8, 373-405.

Bris, A., and Cabolis, C., 2008. The value of investor protection: Evidence from cross-border mergers. Review of Financial Studies 21, 605-648.

Bruner, R. F., 2004. Applied Mergers and Acquisitions. New York: John Wiley \& Sons.

Betton, S., Eckbo, B.E., Thorburn, K.S., 2009. Merger negotiations and the toehold puzzle. Journal of Financial Economics 91, 158-178.

Buysschaert, A., Deloof, M., Jegers, M., 2004. Equity sales in Belgian corporate groups: Expropriation of minority shareholders? A clinical study. Journal of Corporate Finance 10, 81-103.

Carney, William J., 2006. The costs of being public after Sarbanes-Oxley: The irony of 'going private'. Emory Law Journal 55, 141-160.

Chan, K., Chan, Y.-C., Fong, W. M., 2004. Free float and market liquidity: A study of Hong Kong government intervention. Journal of Financial Research 27, 179-197.

Claessens, S., Djankov, S., Lang, L., 2000. The separation of ownership and control in East Asian corporations. Journal of Financial Economics 58, 81-112.

Commissions of European Communities, 2007. Report on the implementation of the Directive on Takeover Bids, Commission Staff Working Document, SEC(2007) 268.

Croci, E., 2007. Corporate raiders, performance, and governance in Europe. European Financial Management, 13, 949-978.

Demsetz, H., Lehn, K., 1985. The structure of corporate ownership: Causes and consequences. Journal of Political Economy 93, 1155-1177.

Djankov, S., La Porta, R., Lopez-de-Silanes, F., Shleifer, A., 2008. The law and economics of selfdealing. Journal of Financial Economics 88, 430-465.

Djankov, S., McLiesh, C., Shleifer, A., 2007. Private credit in 129 countries. Journal of Financial Economics 84, 299-329.

Dyck, A., Zingales, L., 2004. Private benefits of control. An international comparison. Journal of Finance 59, 537-600.

Dyck, A., Volchkova, N., Zingales, L., 2008. The corporate governance role of the media: Evidence from Russia. Journal of Finance 63, 1093-1135. 
Faccio, M., Lang, L.H.P., 2002. The ultimate ownership of western european corporations. Journal of Financial Economics 65, 365-395.

Faccio, M., Masulis, R.W., 2005. The choice of payment method in European mergers and acquisitions. Journal of Finance 60, 1345-1388.

Faccio, M., Stolin, D., 2006. Expropriation vs. proportional sharing in corporate acquisitions. Journal of Business 79, 1413-1444.

Ferreira, M.A., Matos, P., 2008. The colors of investors' money: The role of institutional investors around the world. Journal of Financial Economics 88, 499-533.

Greenwood, Robin M., 2009. Trading restrictions and stock prices. Review of Financial Studies 22, 509-539

Guiso, L., Sapienza, P., Zingales, L., 2008. Trusting the stock market. Journal of Finance 63, 25572600.

Harris, M., Raviv, A., 1991. The theory of capital structure. Journal of Finance 46, 297-355.

Holderness, C.G., Sheehan, D.P., 1988. The role of majority shareholders in publicly held corporations: An exploratory analysis. Journal of Financial Economics 20, 317-346.

Holmen, M., Knopf, J.D., 2004. Minority shareholder protections and the private benefits of control for Swedish mergers. Journal of Financial and Quantitative Analysis 39, 167-191.

Huang Y., Walkling, R.A., 1987. Target abnormal returns associated with acquisition announcements: Payment, acquisition form, and managerial resistance. Journal of Financial Economics 19, 329-349.

Jenkinson, T., Ljungqvist, A., 2001. The role of hostile stakes in German corporate governance. Journal of Corporate Finance 7, 397-446

Klasa, S., 2007, Why do controlling families of public firms sell their remaining ownership stake? Journal of Financial and Quantitative Analysis 42, 339-368.

La Porta, R., Lopez-de-Silanes, F., Shleifer, A., 1999. Corporate ownership around the world. Journal of Finance 54, 471-517.

La Porta, R., Lopez-de-Silanes, F., Shleifer, A., Vishny, R., 1997. Legal determinants of external finance. Journal of Finance 52, 1131-1150.

La Porta, R., Lopez-de-Silanes, F., Shleifer, A., Vishny, R., 1998. Law and finance. Journal of Political Economy 106, 1113-1155.

La Porta, R., Lopez-de-Silanes, F., Shleifer, A., Vishny, R., 2000. Investor protection and corporate governance. Journal of Financial Economics 58-1, 1-25.

Leuz, Christian, 2007, Was the Sarbanes-Oxley Act of 2002 really this costly? A discussion of evidence from event returns and going-private decisions. Journal of Accounting and Economics 44, 146-165.

Leuz, C., Triantis, A.J., Wang, T., 2008, Why do firms go dark? Causes and economic consequences of voluntary SEC deregistrations. Journal of Accounting and Economics 45, 181-208.

Levine, R., Zervos, S., 1998. Stock markets, banks, and economic growth. American Economic Review 88, 537-558.

Litvak, K., 2007, The effect of the Sarbanes-Oxley Act on non-U.S. companies cross-listed in the U.S. Journal of Corporate Finance 13, 195-228.

Martynova, M., Renneboog, L., 2006. Mergers and Acquisitions in Europe, in L. Renneboog (Ed.), Advances in Corporate Finance and Asset Pricing, Elsevier, Amsterdam.

Massa, M., Ferreira, M.A., Matos, P.P., 2009. Shareholders at the gate? Institutional investors and cross-border mergers and acquisitions. EFA 2007 Ljubljana Meetings Paper.

Marosi, A., Massoud, N., 2008. 'You can enter, but you cannot leave...' - U.S. securities markets and foreign firms. Journal of Finance 63, 2477-2506.

Miller, G., 2006. The press as watchdog for accounting fraud. Journal of Accounting Research 44, 1001-1033. 
Morck R., Shleifer, A., Vishny, R.W., 1990. Do managerial objectives drive bad acquisitions? Journal of Finance 45, 31-48.

Pagano, M., Volpin, P.F., 2001. The political economy of finance. Oxford Review of Economic Policy 17, 502-519.

Pagano, M., Volpin, P.F., 2006. Shareholder protection, stock market development, and politics. Journal of the European Economic Association, 315-341

Rajan, R.G., Zingales, L., 2003. The great reversals: The politics of the financial development in the twentieth century. Journal of Financial Economics 69, 5-50.

Rossi, S., Volpin, P. 2004. Cross-country determinants of mergers and acquisitions. Journal of Financial Economics 74, 277-304.

Schwert, W.G., 1996. Markup pricing in mergers and acquisitions. Journal of Financial Economics 41, 153-192.

Shleifer, A., Vishny, R., 1989. Management entrenchment: The case of management-specific investments. Journal of Financial Economics 25, 123-139.

Shleifer, A., Vishny, R.W., 1997. A survey of corporate governance. Journal of Finance 52, 737783.

Spamann, H., 2006. On the Insignificance and/or endogeneity of La Porta et al.'s "Antidirector Rights Index" under consistent coding. Law Working paper N. 67/2006, European Corporate Governance Institute.

Travlos, G. N., 1987. Corporate takeover bids, method of payment, and bidding firm's stock returns. Journal of Finance 52, 943-963.

Weston, M., Mitchell, M., Mulherin, J.H., 2004. Corporate Takeovers, Restructurings and Corporate Governance, $4^{\text {th }}$ ed. Pearson Education, Upper Saddle River, NJ.

Zhang, Ivy X., 2007, Economic consequences of the Sarbanes-Oxley Act of 2002. Journal of Accounting and Economics 44, 74-115. 


\section{Appendix: Variable Definitions}

\begin{tabular}{|c|c|}
\hline Variable & Definition \\
\hline Turnover over GDP & $\begin{array}{l}\text { Ratio of the value of the trades of domestic equities on domestic exchanges in the } \\
\text { year before the deal in the target country to the country's GDP. The variable is } \\
\text { from the World Bank's World Development Indicators. }\end{array}$ \\
\hline $\begin{array}{l}\text { Turnover over Market } \\
\text { Capitalization }\end{array}$ & $\begin{array}{l}\text { Ratio of the value of the trades of domestic equities on domestic exchanges in the } \\
\text { year before the deal in the target country to the country's domestic market } \\
\text { capitalization. The variable is from the World Bank's World Development Indicators. }\end{array}$ \\
\hline English Origin & $\begin{array}{l}\text { Dummy variable that takes the value of } 1 \text { if the legal origin of the target firm } \\
\text { country is English common law (LLSV, 1998) }\end{array}$ \\
\hline DLLS Index & Djankov et al. (2008) revised anti-director-rights index. \\
\hline Log GDP & $\begin{array}{l}\text { Log of the target's country GDP per capita (US\$ 2000) in the year before the deal. } \\
\text { The variable is from the World Bank's World Development Indicators. }\end{array}$ \\
\hline Private Credit & $\begin{array}{l}\text { The ratio of credit from deposit-taking financial institutions to the private sector } \\
\text { (IFS lines } 22 d \text { and } 42 d \text { ) to GDP (IFS line 99b), expressed as a percentage, for the } \\
\text { year before the transactions. IFS is the IMF's International Financial Statistics. }\end{array}$ \\
\hline GDP Growth & $\begin{array}{l}\text { Annual growth rate of target's country GDP in the year before the deal. The } \\
\text { variable is from the World Bank's World Development Indicators. }\end{array}$ \\
\hline TV & $\begin{array}{l}\text { Percentage of households with television (\%) at the end of the year before the } \\
\text { deal. The variable is from the World Bank's World Development Indicators. }\end{array}$ \\
\hline Domestic & $\begin{array}{l}\text { Dummy variable that takes the value of } 1 \text { when the bidder and the target belong to } \\
\text { the same country. }\end{array}$ \\
\hline Diversifying & $\begin{array}{l}\text { Dummy variable that takes the value of } 1 \text { when the bidder and the target belong to } \\
\text { a different industry. }\end{array}$ \\
\hline Size & $\begin{array}{l}\text { The firm's market value of equity in US } \$ \text { at the end of the year before the deal } \\
\text { (Worldscope Item WC07210). }\end{array}$ \\
\hline Collateral & $\begin{array}{l}\text { Ratio of tangible assets to total assets at the end of the year before the deal } \\
\text { (WC02501/WC02999). }\end{array}$ \\
\hline ROA & Return on assets in the year before the deal (WC08326). \\
\hline Cash Holding & $\begin{array}{l}\text { Ratio of cash plus tradable securities over total assets at the end of the year before } \\
\text { the deal (WC02001/WC02999). }\end{array}$ \\
\hline Leverage & $\begin{array}{l}\text { Ratio of book value of financial debt as a percentage of the book value of total assets } \\
\text { at the end of the year before the deal (WC03251/WC02999). }\end{array}$ \\
\hline Market-to-book & $\begin{array}{l}\text { Ratio of market value of equity in US\$ (WC07210) divided by common equity in } \\
\text { US\$ at the end of the year before the deal (WC07220). }\end{array}$ \\
\hline Stock-Price Performance & Stock-price performance over the year before the deal (WC05070). \\
\hline Own. Before & Percentage of the target firm's equity held by the bidder before the transaction. \\
\hline Own. After & Percentage of the target firm's equity held by the bidder after the transaction. \\
\hline Cash & $\begin{array}{l}\text { Dummy variable that takes the value of } 1 \text { if the method of payment in the deal is } \\
\text { cash (at least } 80 \% \text { of the deal value). }\end{array}$ \\
\hline Taken Private & $\begin{array}{l}\text { Dummy variable that takes the value of } 1 \text { when the deal aims at delisting the target } \\
\text { firm. }\end{array}$ \\
\hline Run-up & $\begin{array}{l}\text { Cumulative abnormal return in the period immediately before the acquisition } \\
\text { announcements. The run-up period is }(-42,-3) \text { when the event window }(-2,+2) \text { is } \\
\text { used, }(-42,-6) \text { when the event window }(-5,5) \text { is used, and finally }(-42,-11) \text { when } \\
\text { the event window }(-10,+10) \text { is used as the dependent variable in the regression. }\end{array}$ \\
\hline
\end{tabular}




\section{Appendix: Variable Definitions (cont.)}

Variable

\section{Definition}

\begin{tabular}{|c|c|}
\hline Family & $\begin{array}{l}\text { Dummy variable that takes the value of } 1 \text { when the controlling shareholder of the } \\
\text { bidding firm is a family. }\end{array}$ \\
\hline State & $\begin{array}{l}\text { Dummy variable that takes the value of } 1 \text { when the controlling shareholder of the } \\
\text { bidding firm is the state. }\end{array}$ \\
\hline Financial & $\begin{array}{l}\text { Dummy variable that takes the value of } 1 \text { when the controlling shareholder of the } \\
\text { bidding firm is a financial institution. }\end{array}$ \\
\hline Cont. by Widely Held & $\begin{array}{l}\text { Dummy variable that takes the value of } 1 \text { when the controlling shareholder of the } \\
\text { bidding firm is a widely held firm (non-financial). }\end{array}$ \\
\hline $\begin{array}{l}\text { Cont. by Widely Held } \\
\text { financial }\end{array}$ & $\begin{array}{l}\text { Dummy variable that takes the value of } 1 \text { when the controlling shareholder of the } \\
\text { bidding firm is a widely held financial institution. }\end{array}$ \\
\hline Miscellaneous & $\begin{array}{l}\text { Dummy variable that takes the value of } 1 \text { when the controlling shareholder of the } \\
\text { bidding firm is a foundation, employees, etc. It is a residual category. }\end{array}$ \\
\hline Widely held & $\begin{array}{l}\text { Dummy variable that takes the value of } 1 \text { when the bidding firm is a widely held } \\
\text { firm. }\end{array}$ \\
\hline Widely Held Financial & $\begin{array}{l}\text { Dummy variable that takes the value of } 1 \text { when the controlling shareholder of the } \\
\text { bidding firm is a widely held financial institution. }\end{array}$ \\
\hline Merger & $\begin{array}{l}\text { Dummy variable that takes the value of } 1 \text { if, according to Lexis/Nexis articles, the } \\
\text { deal form is a merger. }\end{array}$ \\
\hline Block & $\begin{array}{l}\text { Dummy variable that takes the value of } 1 \text { if, according to Lexis/Nexis articles, the } \\
\text { deal form is a block purchase. }\end{array}$ \\
\hline Open market & $\begin{array}{l}\text { Dummy variable that takes the value of } 1 \text { if, according to Lexis/Nexis articles, the } \\
\text { deal form is an open-market purchase. }\end{array}$ \\
\hline Tender Offer & $\begin{array}{l}\text { Dummy variable taking value } 1 \text { if, according to Lexis/Nexis articles, the deal form is } \\
\text { a tender offer. }\end{array}$ \\
\hline Block/Tender Offer & $\begin{array}{l}\text { Dummy variable taking value } 1 \text { if, according to Lexis/Nexis articles, the deal form is } \\
\text { a block purchase immediately followed by a mandatory tender offer. }\end{array}$ \\
\hline
\end{tabular}




\section{Table 1: Sample Construction}

The table reports the steps used to build the database. Deals are subdivided according to the target firm's region. All mergers and acquisitions are from the Thomson ONE Banker database.

All acquisitions from Thomson ONE Banker Mergers and acquisitions database that satisfy the following criteria:

- Country is between those reported below:

Europe: Austria,Belgium, Bulgaria, Croatia, Czech R., Denmark, Estonia, Finland, France, Germany, Greece, Iceland, Ireland, Italy, Latvia, Lithuania, Luxembourg, Netherlands, Norway, Poland, Portugal, Romania, Russia, Spain, Slovak R., Slovenia, Sweden, Switzerland, Turkey, UK, Ukraine.

Australia \& New Zealand: Australia, New Zealand.

Africa: South Africa.

Asia: China, Hong Kong, India, Indonesia, Israel, Japan, Korea, Malaysia, Philippines, Singapore, Thailand, Vietnam

Americas: Argentina, Bolivia, Brazil, Canada, Chile, Colombia, Ecuador, Mexico, Paraguay, Peru, Uruguay, U.S.A., Venezuela

- Target is a public firm

- Announcement date from 01.01.1989 to 12.31.2005

- Deal value $>\$ 1 m$

- The deal is completed

- Owned after $>30 \%$

- $\%$ of target equity acquired at least $5 \%$

Total

Deals lost because:

Target and bidder do not have the same ultimate parent company according to Thomson One Banker

Total

Deals that failed double-check with Lexis-Nexis

Bidder's ownership before the acquisition is above $90 \%$ 


\section{Table 2. Descriptive Statistics}

The table presents descriptive statistics about all variables used in the empirical analysis. Variable definitions are in the Appendix .

\begin{tabular}{|c|c|c|c|c|c|c|}
\hline & Mean & Median & Minimum & Maximum & $\begin{array}{l}\text { Standard } \\
\text { Deviation }\end{array}$ & N. Obs \\
\hline \multicolumn{7}{|l|}{ Country level Variables } \\
\hline Turnover over GDP & 0.6241 & 0.4345 & 0.0047 & 3.2630 & 0.6422 & 1174 \\
\hline Turnover over Mkt. Cap & 0.7151 & 0.6054 & 0.0094 & 3.4432 & 0.5244 & 1174 \\
\hline Market Cap (\% over GDP) & 0.7874 & 0.6534 & 0.0536 & 3.2201 & 0.5080 & 1137 \\
\hline English origin & 0.4719 & & & & & 1174 \\
\hline Private Credit & 1.0708 & 1.0857 & 0.1050 & 2.0032 & 0.4400 & 1156 \\
\hline Log GDP & 9.6964 & 9.9987 & 5.7813 & 10.7424 & 1.0055 & 1174 \\
\hline GDP Growth (\%) & 2.7784 & 2.9200 & -10.8900 & 11.7300 & 2.4424 & 1174 \\
\hline Televisions & 91.3608 & 96.7500 & 13.5800 & 101.4700 & 13.8531 & 1091 \\
\hline DLLS Index & 3.5472 & 3.5000 & 1.0000 & 5.0000 & 0.9101 & 1166 \\
\hline \multicolumn{7}{|l|}{ Firm level Variables } \\
\hline Size & 1177.52 & 220.74 & 582.00 & 55175.09 & 3941.89 & 868 \\
\hline Collateral & 0.3118 & 0.2745 & 0.0000 & 0.9827 & 0.2556 & 867 \\
\hline ROA & 2.2382 & 3.9400 & -1013.6200 & 149.1600 & 37.5579 & 854 \\
\hline Cash holding & 0.1372 & 0.0758 & 0.0000 & 0.9872 & 0.1648 & 794 \\
\hline Leverage & 0.1210 & 0.0582 & 0.0000 & 0.9125 & 0.1540 & 873 \\
\hline Market-to-book & 3.2986 & 1.3848 & 0.0066 & 563.4595 & 22.0640 & 845 \\
\hline Stock Price Performance & 0.1029 & 0.0000 & -0.9746 & 8.4787 & 0.6794 & 861 \\
\hline Owned Directly Before (\%) & 60.23 & 62.90 & 0.00 & 90.00 & 21.11 & 1174 \\
\hline Owned Directly After (\%) & 93.06 & 100.00 & 34.00 & 100.00 & 13.16 & 1174 \\
\hline Family & 0.4209 & & & & & 1100 \\
\hline State & 0.1091 & & & & & 1100 \\
\hline Financial & 0.1136 & & & & & 1100 \\
\hline Contr. WH & 0.0473 & & & & & 1100 \\
\hline Contr. Fin. & 0.0382 & & & & & 1100 \\
\hline Miscellaneous & 0.0191 & & & & & 1100 \\
\hline Widely Held Fin. & 0.0418 & & & & & 1100 \\
\hline \multicolumn{7}{|l|}{ Deal specific Variables } \\
\hline Domestic & 0.7206 & & & & & 1174 \\
\hline Diversifying & 0.4830 & & & & & 1174 \\
\hline Cash deal & 0.6576 & & & & & 1174 \\
\hline Taken Private & 0.8024 & & & & & 1174 \\
\hline Run-up & 0.0388 & 0.0260 & -2.4982 & 3.4130 & 0.2579 & 1174 \\
\hline Block & 0.0992 & & & & & 1058 \\
\hline Merger & 0.2250 & & & & & 1058 \\
\hline Open market transactions & 0.0123 & & & & & 1058 \\
\hline Tender Offer & 0.6465 & & & & & 1058 \\
\hline
\end{tabular}




\section{Table 3 . Correlations Between Country-level Variables}

The table presents the pair wise correlations between country variables. The variables are defined in the Appendix. The symbol * denotes that the pair wise correlation is statistical significance at the $5 \%$ level.

\begin{tabular}{|c|c|c|c|c|c|c|c|c|c|}
\hline & $\begin{array}{l}\text { Turnover } \\
\text { over GDP }\end{array}$ & $\begin{array}{c}\text { Turnover } \\
\text { over Mkt } \\
\text { Cap. }\end{array}$ & $\begin{array}{c}\text { Common } \\
\text { Law } \\
\text { Dummy }\end{array}$ & $\begin{array}{c}\text { Market } \\
\text { Cap (\% } \\
\text { GDP) } \\
\end{array}$ & $\begin{array}{c}\text { Private } \\
\text { Credit }\end{array}$ & Log (GDP) & $\begin{array}{c}\text { GDP } \\
\text { Growth }\end{array}$ & TV & DLLS Index \\
\hline Turnover over GDP & 1 & & & & & & & & \\
\hline Turnover over Mkt Cap. & $0.6171 *$ & 1 & & & & & & & \\
\hline Common Law Dummy & $0.3464^{*}$ & $0.1309 *$ & 1 & & & & & & \\
\hline Market cap (\% GDP) & $0.6565^{*}$ & $0.0890^{*}$ & $0.3978^{*}$ & 1 & & & & & \\
\hline Private Credit & $0.5365^{*}$ & $0.1360 *$ & $0.3016^{*}$ & $0.5498^{*}$ & 1 & & & & \\
\hline $\log (G D P)$ & $0.2774^{*}$ & $-0.1034 *$ & -0.0314 & $0.2841^{*}$ & $0.5829 *$ & 1 & & & \\
\hline GDP growth & $0.1600^{*}$ & $0.1005^{*}$ & $0.3030^{*}$ & $0.2047^{*}$ & $-0.0960 *$ & $-0.2556^{*}$ & 1 & & \\
\hline TV & $0.1543^{*}$ & $-0.2391 *$ & -0.0587 & $0.1613^{*}$ & $0.4110^{*}$ & 0.7949* & $-0.1879 *$ & 1 & \\
\hline DLLS Index & 0.0322 & -0.0109 & $0.4302^{*}$ & $0.1671^{*}$ & -0.0541 & $-0.3150 *$ & 0.0670* & $-0.2860 *$ & 1 \\
\hline
\end{tabular}




\section{Table 4. Abnormal Returns at Country Level}

The table presents the event study results by country for the whole sample of targets involved in increasein-ownership transactions during the period 1989-2005. The 13 countries not included in the table do not have any observation in the sample. These are the following: Bulgaria, Croatia, Iceland, Lithuania, Romania, Slovenia, Ukraine, Venezuela, Uruguay, Paraguay, Ecuador, Bolivia, and Vietnam.

\begin{tabular}{|c|c|c|c|c|c|c|c|}
\hline \multirow[b]{2}{*}{ Country } & \multicolumn{2}{|c|}{$\operatorname{CAR}(-2,+2)$} & \multicolumn{2}{|c|}{$\operatorname{CAR}(-5,+5)$} & \multicolumn{2}{|c|}{ CAR $(-10,+10)$} & \multirow[b]{2}{*}{ \# Obs. } \\
\hline & Mean & Median & Mean & Median & Mean & Median & \\
\hline Argentina & $12.42 \%$ & $11.06 \%$ & $16.61 \%$ & $16.99 \%$ & $16.26 \%$ & $12.84 \%$ & 12 \\
\hline Australia & $15.22 \%$ & $9.68 \%$ & $15.10 \%$ & $13.97 \%$ & $15.71 \%$ & $14.75 \%$ & 49 \\
\hline Austria & $16.16 \%$ & $6.14 \%$ & $18.95 \%$ & $7.63 \%$ & $24.58 \%$ & $14.78 \%$ & 7 \\
\hline Belgium & $11.83 \%$ & $7.61 \%$ & $13.27 \%$ & $8.74 \%$ & $14.79 \%$ & $11.11 \%$ & 18 \\
\hline Brazil & $9.29 \%$ & $2.92 \%$ & $9.44 \%$ & $2.82 \%$ & $11.70 \%$ & $4.32 \%$ & 32 \\
\hline Canada & $15.94 \%$ & $13.49 \%$ & $17.87 \%$ & $14.80 \%$ & $18.63 \%$ & $14.90 \%$ & 66 \\
\hline Chile & $14.16 \%$ & $7.21 \%$ & $19.75 \%$ & $13.83 \%$ & $19.04 \%$ & $13.14 \%$ & 10 \\
\hline China & $3.36 \%$ & $2.98 \%$ & $1.95 \%$ & $2.35 \%$ & $5.90 \%$ & $5.12 \%$ & 9 \\
\hline Colombia & $-10.69 \%$ & $5.65 \%$ & $-8.79 \%$ & $9.25 \%$ & $-5.71 \%$ & $13.01 \%$ & 5 \\
\hline Czech Rep. & $7.73 \%$ & $0.24 \%$ & $8.06 \%$ & $6.89 \%$ & $7.56 \%$ & $4.59 \%$ & 6 \\
\hline Denmark & $12.00 \%$ & $5.04 \%$ & $13.85 \%$ & $5.74 \%$ & $13.24 \%$ & $5.56 \%$ & 5 \\
\hline Estonia & $2.37 \%$ & $2.37 \%$ & $6.18 \%$ & $6.18 \%$ & $-5.14 \%$ & $-5.14 \%$ & 1 \\
\hline Finland & $8.82 \%$ & $3.83 \%$ & $8.63 \%$ & $4.13 \%$ & $8.30 \%$ & $7.16 \%$ & 12 \\
\hline France & $2.31 \%$ & $0.25 \%$ & $2.51 \%$ & $0.49 \%$ & $10.73 \%$ & $4.32 \%$ & 94 \\
\hline Germany & $7.71 \%$ & $5.86 \%$ & $9.51 \%$ & $6.86 \%$ & $10.94 \%$ & $10.94 \%$ & 38 \\
\hline Greece & $1.42 \%$ & $0.77 \%$ & $1.67 \%$ & $2.94 \%$ & $4.16 \%$ & $4.13 \%$ & 4 \\
\hline Hong Kong & $26.49 \%$ & $20.27 \%$ & $33.04 \%$ & $30.81 \%$ & $36.28 \%$ & $32.51 \%$ & 37 \\
\hline India & $11.29 \%$ & $10.08 \%$ & $13.88 \%$ & $10.49 \%$ & $17.88 \%$ & $20.18 \%$ & 34 \\
\hline Indonesia & $5.69 \%$ & $3.69 \%$ & $4.27 \%$ & $4.53 \%$ & $7.52 \%$ & $7.99 \%$ & 7 \\
\hline Ireland-Rep & $15.72 \%$ & $15.72 \%$ & $22.72 \%$ & $22.72 \%$ & $22.71 \%$ & $22.71 \%$ & 1 \\
\hline Israel & $16.70 \%$ & $17.32 \%$ & $17.44 \%$ & $17.05 \%$ & $12.75 \%$ & $10.86 \%$ & 9 \\
\hline Italy & $10.28 \%$ & $4.96 \%$ & $12.74 \%$ & $8.90 \%$ & $16.27 \%$ & $12.77 \%$ & 58 \\
\hline Japan & $6.78 \%$ & $5.91 \%$ & $8.68 \%$ & $8.50 \%$ & $7.53 \%$ & $6.57 \%$ & 159 \\
\hline Latvia & $29.60 \%$ & $29.60 \%$ & $23.24 \%$ & $23.24 \%$ & $18.93 \%$ & $18.93 \%$ & 1 \\
\hline Luxembourg & $0.26 \%$ & $0.01 \%$ & $-2.17 \%$ & $2.25 \%$ & $-0.60 \%$ & $6.69 \%$ & 6 \\
\hline Malaysia & $9.57 \%$ & $6.87 \%$ & $9.65 \%$ & $7.39 \%$ & $13.17 \%$ & $10.66 \%$ & 16 \\
\hline Mexico & $3.38 \%$ & $-0.46 \%$ & $2.29 \%$ & $-0.96 \%$ & $4.16 \%$ & $2.74 \%$ & 6 \\
\hline Netherlands & $11.35 \%$ & $5.88 \%$ & $15.66 \%$ & $6.64 \%$ & $14.79 \%$ & $8.23 \%$ & 17 \\
\hline New Zealand & $10.37 \%$ & $9.29 \%$ & $9.68 \%$ & $8.81 \%$ & $10.02 \%$ & $11.16 \%$ & 28 \\
\hline Norway & $12.54 \%$ & $9.66 \%$ & $19.34 \%$ & $26.66 \%$ & $22.40 \%$ & $23.47 \%$ & 6 \\
\hline Peru & $-1.27 \%$ & $-0.18 \%$ & $-0.55 \%$ & $-0.17 \%$ & $0.62 \%$ & $0.22 \%$ & 3 \\
\hline Philippines & $9.00 \%$ & $6.64 \%$ & $10.51 \%$ & $14.01 \%$ & $10.84 \%$ & $14.06 \%$ & 3 \\
\hline Poland & $0.60 \%$ & $0.79 \%$ & $-1.04 \%$ & $-2.79 \%$ & $5.51 \%$ & $4.50 \%$ & 15 \\
\hline Portugal & $4.43 \%$ & $2.62 \%$ & $2.88 \%$ & $1.07 \%$ & $1.16 \%$ & $-0.13 \%$ & 16 \\
\hline Russian Fed & $-28.99 \%$ & $-28.99 \%$ & $-33.37 \%$ & $-33.37 \%$ & $-31.10 \%$ & $-31.10 \%$ & 1 \\
\hline Singapore & $14.73 \%$ & $12.78 \%$ & $17.25 \%$ & $15.17 \%$ & $18.97 \%$ & $16.96 \%$ & 35 \\
\hline Slovak Rep & $4.95 \%$ & $4.95 \%$ & $1.55 \%$ & $1.55 \%$ & $2.13 \%$ & $2.13 \%$ & 1 \\
\hline South Africa & $7.98 \%$ & $4.76 \%$ & $8.26 \%$ & $11.47 \%$ & $9.45 \%$ & $11.05 \%$ & 25 \\
\hline South Korea & $11.58 \%$ & $5.51 \%$ & $11.21 \%$ & $12.57 \%$ & $6.51 \%$ & $8.89 \%$ & 9 \\
\hline Spain & $10.40 \%$ & $7.74 \%$ & $11.89 \%$ & $13.58 \%$ & $10.71 \%$ & $13.94 \%$ & 21 \\
\hline Sweden & $15.11 \%$ & $13.19 \%$ & $14.86 \%$ & $10.67 \%$ & $15.58 \%$ & $10.63 \%$ & 24 \\
\hline Switzerland & $16.95 \%$ & $14.58 \%$ & $16.79 \%$ & $14.01 \%$ & $19.24 \%$ & $16.81 \%$ & 13 \\
\hline Thailand & $13.83 \%$ & $7.29 \%$ & $15.73 \%$ & $17.49 \%$ & $12.55 \%$ & $15.58 \%$ & 10 \\
\hline Turkey & $-14.82 \%$ & $-14.82 \%$ & $-1.99 \%$ & $-1.99 \%$ & $17.40 \%$ & $17.40 \%$ & 1 \\
\hline United & & & & & & & \\
\hline Kingdom & $26.03 \%$ & $14.20 \%$ & $27.00 \%$ & $15.22 \%$ & $27.57 \%$ & $17.99 \%$ & 37 \\
\hline United & & & & & & & \\
\hline States & $18.45 \%$ & $13.18 \%$ & $19.46 \%$ & $15.93 \%$ & $18.82 \%$ & $16.93 \%$ & 207 \\
\hline Total & $11.95 \%$ & $7.27 \%$ & $13.28 \%$ & $9.25 \%$ & $14.51 \%$ & $11.20 \%$ & 1174 \\
\hline
\end{tabular}




\section{Table 5. Abnormal Returns \& Stock Market Development}

The table analyzes the relationship between cumulative abnormal returns in the event windows $(-2,+2),(-$ $5,+5)$ and $(-10,+10)$ and stock market development proxies described in Section 2.1 for the whole sample of targets involved in increase-in-ownership transactions during the period 1989-2005.

\section{Panel A: Turnover/GDP}

\begin{tabular}{|c|c|c|c|}
\hline & $\operatorname{CAR}(-2,+2)$ & $\operatorname{CAR}(-5,+5)$ & CAR $(-10,+10)$ \\
\hline \multirow[t]{2}{*}{ Full Sample } & $11.95 \%$ & $13.28 \%$ & $14.51 \%$ \\
\hline & 1174 & 1174 & 1174 \\
\hline \multirow[t]{2}{*}{ Bottom Quartile (Q1) } & $7.12 \%$ & $7.85 \%$ & $10.37 \%$ \\
\hline & 294 & 294 & 294 \\
\hline \multirow[t]{2}{*}{ Median Quartiles (Q2) } & $11.47 \%$ & $12.86 \%$ & $13.77 \%$ \\
\hline & 574 & 574 & 574 \\
\hline \multirow[t]{2}{*}{ Top Quartile (Q3) } & $17.50 \%$ & $19.30 \%$ & $19.89 \%$ \\
\hline & 306 & 306 & 306 \\
\hline \multicolumn{4}{|c|}{ Test for difference between top and bottom quartiles } \\
\hline (Q3)-(Q1) & $10.38 \%$ & $11.45 \%$ & $9.52 \%$ \\
\hline t-stat & 5.9856 & 6.1605 & 4.7555 \\
\hline$p$-value & 0.0000 & 0.0000 & 0.0000 \\
\hline \multicolumn{4}{|c|}{ Panel B: Turnover/Market Capitalization } \\
\hline & CAR $(-2,+2)$ & $\operatorname{CAR}(-5,+5)$ & CAR $(-10,+10)$ \\
\hline \multirow[t]{2}{*}{ Full sample } & $11.95 \%$ & $13.28 \%$ & $14.51 \%$ \\
\hline & 1174 & 1174 & 1174 \\
\hline \multirow[t]{2}{*}{ Bottom Quartile (Q1) } & $9.50 \%$ & $10.66 \%$ & $12.71 \%$ \\
\hline & 294 & 294 & 294 \\
\hline \multirow[t]{2}{*}{ Median Quartiles (Q2) } & $11.97 \%$ & $13.49 \%$ & $15.10 \%$ \\
\hline & 571 & 571 & 571 \\
\hline \multirow[t]{2}{*}{ Top Quartile (Q3) } & $14.25 \%$ & $15.40 \%$ & $15.15 \%$ \\
\hline & 309 & 309 & 309 \\
\hline \multicolumn{4}{|c|}{ Test for difference between top and bottom quartiles } \\
\hline (Q3)-(Q1) & $4.75 \%$ & $4.74 \%$ & $2.44 \%$ \\
\hline t-stat & 2.7834 & 2.6083 & 1.2329 \\
\hline$p$-value & 0.0056 & 0.0093 & 0.2181 \\
\hline
\end{tabular}




\section{Table 6. Regressions with Country-Level Variables}

The table presents the results of cross-sectional regressions in which the dependent variable is the targets' cumulative abnormal return in the event windows $(-2,2),(-5,5)$, and $(-10,10)$. The variables are defined in the Appendix. All regressions include time-fixed effects, whose coefficients are omitted. Clustered robust standard errors at the country level are in parenthesis. The symbols $* * *, * *, *$ denote statistical significance at the $1 \%, 5 \%$, and $10 \%$ levels, respectively.

\begin{tabular}{|c|c|c|c|c|c|c|}
\hline & \multicolumn{2}{|c|}{$\operatorname{CAR}(-2,+2)$} & \multicolumn{2}{|c|}{$\operatorname{CAR}(-5,+5)$} & \multicolumn{2}{|c|}{ CAR $(-10,+10)$} \\
\hline & (1) & (2) & (3) & (4) & (5) & (6) \\
\hline \multirow[t]{2}{*}{ Constant } & $-0.1884^{*}$ & $-0.2441 * *$ & $-0.2187^{* *}$ & $-0.2650 * *$ & -0.1351 & -0.1897 \\
\hline & [0.1017] & [0.1093] & [0.0966] & [0.1089] & [0.1113] & [0.1213] \\
\hline \multirow[t]{2}{*}{ Turnover over GDP } & $0.0648^{* * *}$ & & $0.0629 * * *$ & & $0.0645^{* * *}$ & \\
\hline & [0.0103] & & [0.0123] & & [0.0144] & \\
\hline \multirow[t]{2}{*}{ Turnover over Mkt. Cap } & & $0.0438 * * *$ & & $0.0375^{* *}$ & & $0.0430 * *$ \\
\hline & & [0.0131] & & [0.0151] & & [0.0162] \\
\hline \multirow[t]{2}{*}{ English Origin } & $0.0728 * * *$ & $0.0802 * * *$ & $0.0685^{* * *}$ & $0.0773 * * *$ & $0.0492 * * *$ & $0.0567 * * *$ \\
\hline & [0.0151] & [0.0155] & [0.0164] & [0.0173] & [0.0152] & [0.0158] \\
\hline \multirow[t]{2}{*}{ Market Cap (\% over GDP) } & -0.0225 & 0.0231 & -0.0324 & 0.0109 & -0.0152 & 0.03 \\
\hline & [0.0202] & [0.0194] & {$[0.0246]$} & {$[0.0227]$} & {$[0.0272]$} & [0.0227] \\
\hline \multirow[t]{2}{*}{ Private Credit } & -0.0068 & -0.0052 & 0.0051 & 0.0077 & -0.0337 & -0.032 \\
\hline & {$[0.0183]$} & [0.0183] & {$[0.0211]$} & {$[0.0210]$} & [0.0205] & [0.0202] \\
\hline \multirow[t]{2}{*}{ Log GDP } & $0.0273^{*}$ & $0.0286^{*}$ & $0.0381 * *$ & $0.0398 * *$ & $0.0398 * *$ & $0.0411 * *$ \\
\hline & [0.0157] & [0.0165] & [0.0148] & [0.0157] & {$[0.0166]$} & [0.0174] \\
\hline \multirow[t]{2}{*}{ GDP Growth } & -0.003 & -0.0036 & -0.0026 & -0.0031 & 0 & -0.0006 \\
\hline & {$[0.0035]$} & [0.0033] & {$[0.0032]$} & [0.0031] & [0.0034] & [0.0032] \\
\hline \multirow[t]{2}{*}{ Televisions } & -0.0006 & -0.0002 & $-0.0015^{*}$ & -0.0012 & $-0.0020 * *$ & -0.0016 \\
\hline & [0.0007] & [0.0009] & [0.0007] & [0.0009] & [0.0008] & [0.0010] \\
\hline \multirow[t]{2}{*}{ DLLS Index } & $0.0157^{*}$ & 0.0094 & $0.0195^{* *}$ & 0.0129 & 0.0158 & 0.0095 \\
\hline & [0.0083] & [0.0087] & [0.0084] & [0.0088] & [0.0101] & [0.0101] \\
\hline Adjusted R-squared & 0.1117 & 0.1035 & 0.0962 & 0.0882 & 0.0544 & 0.0488 \\
\hline Observations & 1035 & 1035 & 1035 & 1035 & 1035 & 1035 \\
\hline
\end{tabular}




\section{Table 7. Regressions with Country- and Firm-Level Variables}

The table presents the results of cross-sectional regressions in which the dependent variable is the targets' cumulative abnormal return in the event windows $(-2,2),(-5,5)$, and $(-10,10)$. The variables are defined in the Appendix. Clustered robust standard errors are in parenthesis. All regressions include timefixed effects, whose coefficients are omitted. The symbols $* * *, * *, *$ denote statistical significance at the $1 \%, 5 \%$, and $10 \%$ levels, respectively.

\begin{tabular}{|c|c|c|c|c|c|c|}
\hline & \multicolumn{2}{|c|}{$\operatorname{CAR}(-2,+2)$} & \multicolumn{2}{|c|}{$\operatorname{CAR}(-5,+5)$} & \multicolumn{2}{|c|}{ CAR $(-10,+10)$} \\
\hline & (1) & (2) & (3) & (4) & (5) & (6) \\
\hline Constant & $\begin{array}{r}-0.2396 * * \\
{[0.1130]}\end{array}$ & $\begin{array}{r}-0.2876 * * \\
{[0.1208]}\end{array}$ & $\begin{array}{r}-0.2508 * * \\
{[0.1116]}\end{array}$ & $\begin{array}{r}-0.2987 * * \\
{[0.1144]}\end{array}$ & $\begin{array}{r}-0.1781 \\
{[0.1506]}\end{array}$ & $\begin{array}{r}-0.2371 \\
{[0.1500]}\end{array}$ \\
\hline \multicolumn{7}{|l|}{ Turnover over } \\
\hline GDP & $\begin{array}{r}0.0577^{* * *} \\
{[0.0105]}\end{array}$ & & $\begin{array}{r}0.0598 * * * \\
{[0.0119]}\end{array}$ & & $\begin{array}{r}0.0614^{* * *} \\
{[0.0148]}\end{array}$ & \\
\hline \multicolumn{7}{|l|}{ Turnover over } \\
\hline Mkt. Cap & & $\begin{array}{r}0.0366^{* *} \\
{[0.0142]}\end{array}$ & & $\begin{array}{r}0.0367^{* *} \\
{[0.0138]}\end{array}$ & & $\begin{array}{r}0.0440 * * * \\
{[0.0152]}\end{array}$ \\
\hline English Origin & $\begin{array}{r}0.0492 * * * \\
{[0.0138]}\end{array}$ & $\begin{array}{r}0.0568 * * * \\
{[0.0146]}\end{array}$ & $\begin{array}{r}0.0586 * * * \\
{[0.0164]}\end{array}$ & $\begin{array}{r}0.0668 * * * \\
{[0.0165]}\end{array}$ & $\begin{array}{r}0.0304 \\
{[0.0200]}\end{array}$ & $\begin{array}{c}0.0371 * \\
{[0.0200]}\end{array}$ \\
\hline \multicolumn{7}{|l|}{ Market Cap (\% } \\
\hline over GDP) & [0.0235] & {$[0.0213]$} & [0.0271] & {$[0.0269]$} & {$[0.0340]$} & [0.0293] \\
\hline \multirow[t]{2}{*}{ Private Credit } & 0.0168 & 0.0174 & 0.0294 & 0.0302 & 0.0055 & 0.0052 \\
\hline & {$[0.0212]$} & {$[0.0207]$} & {$[0.0268]$} & [0.0261] & {$[0.0240]$} & {$[0.0230]$} \\
\hline \multirow[t]{2}{*}{ Log GDP } & 0.0105 & 0.0101 & 0.0172 & 0.0169 & 0.015 & 0.0143 \\
\hline & [0.0147] & {$[0.0161]$} & [0.0142] & [0.0159] & [0.0169] & {$[0.0185]$} \\
\hline \multirow[t]{2}{*}{ GDP Growth } & -0.002 & -0.0027 & 0.0005 & -0.0002 & 0.0047 & 0.0039 \\
\hline & [0.0034] & [0.0037] & {$[0.0036]$} & [0.0039] & [0.0038] & {$[0.0039]$} \\
\hline \multirow[t]{2}{*}{ Televisions } & 0.0002 & 0.0006 & 0 & 0.0004 & -0.0003 & 0.0002 \\
\hline & [0.0007] & [0.0009] & [0.0007] & [0.0009] & [0.0010] & {$[0.0012]$} \\
\hline \multirow[t]{2}{*}{ DLLS Index } & $0.0219 * *$ & $0.0156^{*}$ & $0.0215^{* *}$ & $0.0149 *$ & $0.0244 * *$ & $0.0182^{*}$ \\
\hline & [0.0099] & {$[0.0091]$} & [0.0093] & {$[0.0086]$} & [0.0112] & [0.0106] \\
\hline \multirow[t]{2}{*}{ Domestic } & $-0.0314^{*}$ & $-0.0306^{*}$ & $-0.0409 *$ & $-0.0399 *$ & $-0.0567 * *$ & $-0.0560 * *$ \\
\hline & [0.0180] & [0.0180] & [0.0204] & [0.0205] & [0.0226] & [0.0225] \\
\hline \multirow[t]{2}{*}{ Diversifying } & 0.0006 & 0.0025 & -0.0099 & -0.0078 & -0.0072 & -0.0056 \\
\hline & [0.0103] & {$[0.0100]$} & [0.0113] & [0.0109] & {$[0.0136]$} & {$[0.0136]$} \\
\hline \multirow[t]{2}{*}{ Size } & $0.0047^{*}$ & $0.0050 *$ & 0.0041 & 0.0044 & 0.0033 & 0.0036 \\
\hline & [0.0025] & [0.0027] & {$[0.0034]$} & [0.0035] & [0.0046] & [0.0047] \\
\hline \multirow[t]{2}{*}{ ROA } & -0.0001 & -0.0001 & 0.0003 & 0.0003 & 0.0003 & 0.0003 \\
\hline & {$[0.0006]$} & {$[0.0007]$} & [0.0006] & [0.0006] & [0.0008] & [0.0008] \\
\hline \multirow[t]{2}{*}{$M / B$} & -0.0004 & -0.0004 & $-0.0006 * *$ & $-0.0006 * *$ & $-0.0008 * *$ & $-0.0008 * *$ \\
\hline & [0.0003] & [0.0003] & [0.0003] & [0.0003] & [0.0003] & [0.0003] \\
\hline \multirow[t]{2}{*}{ Own. Before } & -0.0008 & -0.0008 & -0.0007 & -0.0007 & -0.0005 & -0.0005 \\
\hline & [0.0006] & [0.0006] & [0.0006] & [0.0006] & [0.0007] & [0.0007] \\
\hline \multirow[t]{2}{*}{ Stock Pr. Perf. } & $-0.0546 * * *$ & $-0.0535 * * *$ & $-0.0552 * * *$ & $-0.0541 * * *$ & $-0.0643 * * *$ & $-0.0630 * * *$ \\
\hline & [0.0128] & [0.0127] & [0.0132] & [0.0132] & [0.0138] & [0.0139] \\
\hline \multirow[t]{2}{*}{ Leverage } & -0.0411 & -0.0339 & -0.0568 & -0.0491 & -0.0753 & -0.0685 \\
\hline & [0.0418] & {$[0.0432]$} & [0.0389] & [0.0389] & {$[0.0652]$} & {$[0.0648]$} \\
\hline \multirow[t]{2}{*}{ Cash Holdings } & 0.0134 & 0.0185 & 0.0354 & 0.0404 & 0.0103 & 0.0164 \\
\hline & {$[0.0345]$} & {$[0.0365]$} & [0.0393] & [0.0413] & {$[0.0325]$} & {$[0.0354]$} \\
\hline
\end{tabular}




\section{Table 7. Regressions with Country- and Firm-Level Variables (cont.)}

The table presents the results of cross-sectional regressions in which the dependent variable is the targets' cumulative abnormal return in the event windows $(-2,2),(-5,5)$, and $(-10,10)$. The variables are defined in the Appendix. Clustered robust standard errors are in parenthesis. All regressions include timefixed effects, whose coefficients are omitted. The symbols $* * *, * *, *$ denote statistical significance at the $1 \%, 5 \%$, and $10 \%$ levels, respectively.

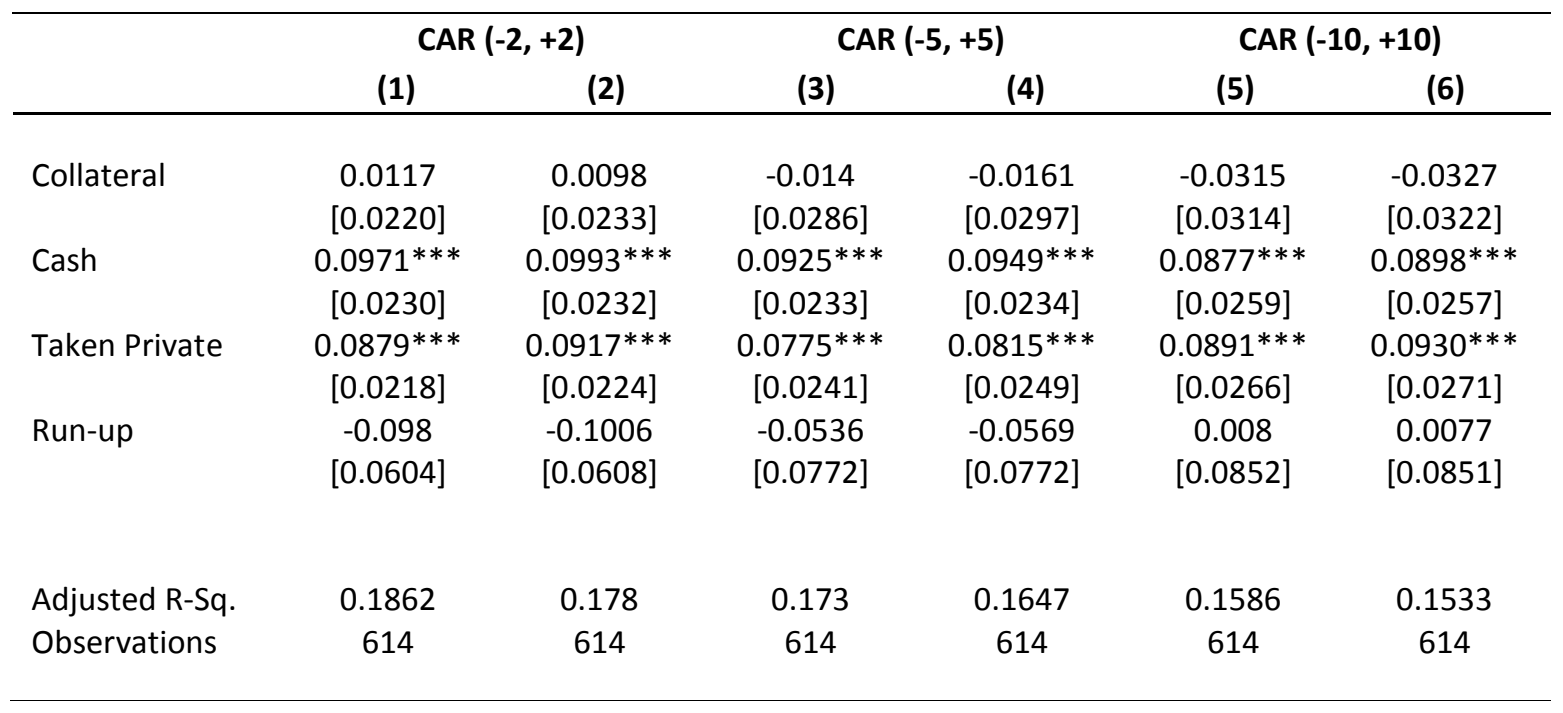




\section{Table 8. Regressions with Ownership Variables}

The table presents the results of cross-sectional regressions in which the dependent variable is the targets' cumulative abnormal return in the event windows $(-2,2),(-5,5)$, and $(-10,10)$. The variables are defined in the Appendix. Clustered robust standard errors are in parenthesis. All regressions include timefixed effects, whose coefficients are omitted. The symbols $* * *, * *, *$ denote statistical significance at the $1 \%, 5 \%$, and $10 \%$ levels, respectively.

\begin{tabular}{|c|c|c|c|c|c|c|}
\hline & \multicolumn{2}{|c|}{ CAR $(-2,+2)$} & \multicolumn{2}{|c|}{ CAR $(-5,+5)$} & \multicolumn{2}{|c|}{ CAR $(-10,+10)$} \\
\hline & (1) & $(2)$ & (3) & (4) & (5) & $(6)$ \\
\hline Constant & $\begin{array}{c}-0.2013^{*} \\
{[0.1150]}\end{array}$ & $\begin{array}{r}-0.2475^{* *} \\
{[0.1198]}\end{array}$ & $\begin{array}{c}-0.2271^{*} \\
{[0.1183]}\end{array}$ & $\begin{array}{r}-0.2733^{* *} \\
{[0.1182]}\end{array}$ & $\begin{array}{r}-0.1441 \\
{[0.1398]}\end{array}$ & $\begin{array}{r}-0.1993 \\
{[0.1371]}\end{array}$ \\
\hline Turnover over & & & & & & \\
\hline GDP & $\begin{array}{r}0.0585^{* * *} \\
{[0.0096]}\end{array}$ & & $\begin{array}{r}0.0606 * * * \\
{[0.0106]}\end{array}$ & & $\begin{array}{r}0.0598 * * * \\
{[0.0131]}\end{array}$ & \\
\hline Turnover over & & & & & & \\
\hline Mkt. Cap & & $\begin{array}{r}0.0350 * * \\
{[0.0133]}\end{array}$ & & $\begin{array}{r}0.0352 * * * \\
{[0.0120]}\end{array}$ & & $\begin{array}{r}0.0404^{* * *} \\
{[0.0132]}\end{array}$ \\
\hline English Origin & $\begin{array}{r}0.0504^{* * *} \\
{[0.0143]}\end{array}$ & $\begin{array}{r}0.0597^{* * *} \\
{[0.0152]}\end{array}$ & $\begin{array}{r}0.0594^{* * *} \\
{[0.0172]}\end{array}$ & $\begin{array}{r}0.0692^{* * *} \\
{[0.0173]}\end{array}$ & $\begin{array}{r}0.0337 \\
{[0.0206]}\end{array}$ & $\begin{array}{r}0.0418^{* *} \\
{[0.0203]}\end{array}$ \\
\hline Market Cap (\% & & & & & & \\
\hline over GDP) & $\begin{array}{r}-0.023 \\
{[0.0224]}\end{array}$ & $\begin{array}{r}0.0194 \\
{[0.0208]}\end{array}$ & $\begin{array}{c}-0.0473 * \\
{[0.0255]}\end{array}$ & $\begin{array}{r}-0.0035 \\
{[0.0257]}\end{array}$ & $\begin{array}{r}-0.0232 \\
{[0.0311]}\end{array}$ & $\begin{array}{r}0.021 \\
{[0.0270]}\end{array}$ \\
\hline Private Credit & $\begin{array}{r}0.0174 \\
{[0.0204]}\end{array}$ & $\begin{array}{r}0.0184 \\
{[0.0196]}\end{array}$ & $\begin{array}{r}0.0309 \\
{[0.0250]}\end{array}$ & $\begin{array}{r}0.0321 \\
{[0.0241]}\end{array}$ & $\begin{array}{r}0.0046 \\
{[0.0210]}\end{array}$ & $\begin{array}{r}0.0049 \\
{[0.0197]}\end{array}$ \\
\hline Log GDP & $\begin{array}{r}0.0075 \\
{[0.0154]}\end{array}$ & $\begin{array}{r}0.0076 \\
{[0.0168]}\end{array}$ & $\begin{array}{r}0.0152 \\
{[0.0149]}\end{array}$ & $\begin{array}{r}0.0154 \\
{[0.0165]}\end{array}$ & $\begin{array}{r}0.0138 \\
{[0.0174]}\end{array}$ & $\begin{array}{r}0.0137 \\
{[0.0188]}\end{array}$ \\
\hline GDP Growth & $\begin{array}{r}-0.0011 \\
{[0.0035]}\end{array}$ & $\begin{array}{r}-0.002 \\
{[0.0039]}\end{array}$ & $\begin{array}{r}0.0012 \\
{[0.0036]}\end{array}$ & $\begin{array}{r}0.0003 \\
{[0.0039]}\end{array}$ & $\begin{array}{r}0.005 \\
{[0.0037]}\end{array}$ & $\begin{array}{r}0.004 \\
{[0.0038]}\end{array}$ \\
\hline Televisions & $\begin{array}{r}0.0003 \\
{[0.0007]}\end{array}$ & $\begin{array}{r}0.0007 \\
{[0.0009]}\end{array}$ & $\begin{array}{r}0.0001 \\
{[0.0007]}\end{array}$ & $\begin{array}{r}0.0005 \\
{[0.0009]}\end{array}$ & $\begin{array}{r}-0.0003 \\
{[0.0010]}\end{array}$ & $\begin{array}{r}0.0001 \\
{[0.0011]}\end{array}$ \\
\hline DLLS Index & $\begin{array}{r}0.0207 * * \\
{[0.0095]}\end{array}$ & $\begin{array}{r}0.0142 \\
{[0.0086]}\end{array}$ & $\begin{array}{r}0.0216^{* *} \\
{[0.0088]}\end{array}$ & $\begin{array}{c}0.0147^{*} \\
{[0.0077]}\end{array}$ & $\begin{array}{r}0.0237^{* *} \\
{[0.0109]}\end{array}$ & $\begin{array}{c}0.0175^{*} \\
{[0.0102]}\end{array}$ \\
\hline Domestic & $\begin{array}{r}-0.0284 \\
{[0.0170]}\end{array}$ & $\begin{array}{r}-0.0274 \\
{[0.0169]}\end{array}$ & $\begin{array}{r}-0.0395^{* *} \\
{[0.0190]}\end{array}$ & $\begin{array}{r}-0.0385^{* *} \\
{[0.0190]}\end{array}$ & $\begin{array}{r}-0.0541 * * \\
{[0.0208]}\end{array}$ & $\begin{array}{r}-0.0532 * * \\
{[0.0204]}\end{array}$ \\
\hline Diversifying & $\begin{array}{r}-0.0007 \\
{[0.0107]}\end{array}$ & $\begin{array}{r}0.0017 \\
{[0.0106]}\end{array}$ & $\begin{array}{r}-0.0103 \\
{[0.0111]}\end{array}$ & $\begin{array}{r}-0.0078 \\
{[0.0109]}\end{array}$ & $\begin{array}{r}-0.0057 \\
{[0.0126]}\end{array}$ & $\begin{array}{r}-0.0037 \\
{[0.0128]}\end{array}$ \\
\hline Size & $\begin{array}{r}0.0045 \\
{[0.0031]}\end{array}$ & $\begin{array}{r}0.0046 \\
{[0.0032]}\end{array}$ & $\begin{array}{r}0.0035 \\
{[0.0042]}\end{array}$ & $\begin{array}{r}0.0036 \\
{[0.0043]}\end{array}$ & $\begin{array}{r}0.0025 \\
{[0.0055]}\end{array}$ & $\begin{array}{r}0.0026 \\
{[0.0056]}\end{array}$ \\
\hline ROA & $\begin{array}{r}-0.0002 \\
{[0.0007]}\end{array}$ & $\begin{array}{r}-0.0002 \\
{[0.0007]}\end{array}$ & $\begin{array}{r}0.0002 \\
{[0.0006]}\end{array}$ & $\begin{array}{r}0.0001 \\
{[0.0007]}\end{array}$ & $\begin{array}{r}0.0003 \\
{[0.0007]}\end{array}$ & $\begin{array}{r}0.0002 \\
{[0.0008]}\end{array}$ \\
\hline $\mathrm{M} / \mathrm{B}$ & $\begin{array}{r}-0.0003 \\
{[0.0003]}\end{array}$ & $\begin{array}{r}-0.0004 \\
{[0.0003]}\end{array}$ & $\begin{array}{r}-0.0006^{* *} \\
{[0.0003]}\end{array}$ & $\begin{array}{r}-0.0006^{* *} \\
{[0.0003]}\end{array}$ & $\begin{array}{r}-0.0007^{* *} \\
{[0.0003]}\end{array}$ & $\begin{array}{r}-0.0008^{* *} \\
{[0.0003]}\end{array}$ \\
\hline Own. Before & $\begin{array}{r}-0.0009 \\
{[0.0006]}\end{array}$ & $\begin{array}{r}-0.0008 \\
{[0.0006]}\end{array}$ & $\begin{array}{r}-0.0007 \\
{[0.0006]}\end{array}$ & $\begin{array}{r}-0.0007 \\
{[0.0007]}\end{array}$ & $\begin{array}{r}-0.0004 \\
{[0.0007]}\end{array}$ & $\begin{array}{r}-0.0004 \\
{[0.0007]}\end{array}$ \\
\hline Stock Pr. Perf. & $\begin{array}{r}-0.0560 * * * \\
{[0.0136]}\end{array}$ & $\begin{array}{r}-0.0549 * * * \\
{[0.0135]}\end{array}$ & $\begin{array}{r}-0.0557 * * * \\
{[0.0140]}\end{array}$ & $\begin{array}{r}-0.0546 * * * \\
{[0.0140]}\end{array}$ & $\begin{array}{r}-0.0632 * * * \\
{[0.0146]}\end{array}$ & $\begin{array}{r}-0.0620 * * * \\
{[0.0146]}\end{array}$ \\
\hline Leverage & $\begin{array}{r}-0.0367 \\
{[0.0478]}\end{array}$ & $\begin{array}{r}-0.0308 \\
{[0.0490]}\end{array}$ & $\begin{array}{r}-0.0498 \\
{[0.0395]}\end{array}$ & $\begin{array}{r}-0.0435 \\
{[0.0394]}\end{array}$ & $\begin{array}{r}-0.0757 \\
{[0.0619]}\end{array}$ & $\begin{array}{r}-0.0707 \\
{[0.0612]}\end{array}$ \\
\hline Cash Holdings & $\begin{array}{r}0.0093 \\
{[0.0350]}\end{array}$ & $\begin{array}{r}0.0131 \\
{[0.0368]}\end{array}$ & $\begin{array}{r}0.0295 \\
{[0.0427]}\end{array}$ & $\begin{array}{r}0.0332 \\
{[0.0442]}\end{array}$ & $\begin{array}{r}-0.0044 \\
{[0.0326]}\end{array}$ & $\begin{array}{r}0.0002 \\
{[0.0347]}\end{array}$ \\
\hline
\end{tabular}




\section{Table 8. Regressions with Ownership Variables - (Cont.)}

The table presents the results of cross-sectional regressions in which the dependent variable is the targets' cumulative abnormal return in the event windows $(-2,2),(-5,5)$, and $(-10,10)$. The variables are defined in the Appendix. Clustered robust standard errors are in parenthesis. All regressions include timefixed effects, whose coefficients are omitted. The symbols $* * *, * *, *$ denote statistical significance at the $1 \%, 5 \%$, and $10 \%$ levels, respectively.

\begin{tabular}{|c|c|c|c|c|c|c|}
\hline & \multicolumn{2}{|c|}{$\operatorname{CAR}(-2,+2)$} & \multicolumn{2}{|c|}{$\operatorname{CAR}(-5,+5)$} & \multicolumn{2}{|c|}{ CAR $(-10,+10)$} \\
\hline & (1) & (2) & (3) & (4) & (5) & (6) \\
\hline \multirow[t]{2}{*}{ Collateral } & 0.0056 & 0.0039 & -0.0255 & -0.0274 & -0.0405 & -0.0414 \\
\hline & [0.0243] & [0.0261] & [0.0277] & [0.0296] & [0.0338] & [0.0351] \\
\hline \multirow[t]{2}{*}{ Cash } & $0.0984 * * *$ & $0.1001 * * *$ & $0.0948 * * *$ & $0.0966 * * *$ & $0.0901 * * *$ & $0.0917 * * *$ \\
\hline & [0.0235] & [0.0234] & [0.0249] & [0.0247] & [0.0283] & [0.0281] \\
\hline \multirow[t]{2}{*}{ Taken Private } & $0.0881 * * *$ & $0.0922 * * *$ & $0.0780 * * *$ & $0.0823 * * *$ & $0.0907 * * *$ & $0.0947^{* * *}$ \\
\hline & [0.0222] & [0.0230] & [0.0251] & [0.0259] & [0.0284] & [0.0290] \\
\hline \multirow[t]{2}{*}{ Run-up } & $-0.0996^{*}$ & $-0.1024^{*}$ & -0.0514 & -0.0549 & 0.012 & 0.0119 \\
\hline & [0.0589] & [0.0592] & [0.0738] & [0.0739] & {$[0.0867]$} & [0.0867] \\
\hline \multirow[t]{2}{*}{ Family } & -0.0107 & -0.0108 & 0.0007 & 0.0005 & -0.0093 & -0.0091 \\
\hline & [0.0187] & {$[0.0184]$} & [0.0192] & [0.0189] & [0.0188] & [0.0185] \\
\hline \multirow[t]{2}{*}{ State } & -0.0138 & -0.0099 & -0.0008 & 0.0032 & -0.0159 & -0.0117 \\
\hline & {$[0.0226]$} & [0.0231] & {$[0.0250]$} & [0.0248] & [0.0237] & [0.0242] \\
\hline \multirow[t]{2}{*}{ Financial } & $-0.0462 *$ & $-0.0473^{*}$ & $-0.0530 *$ & $-0.0542^{*}$ & $-0.0839 * *$ & $-0.0845^{* *}$ \\
\hline & [0.0260] & [0.0257] & [0.0311] & [0.0309] & [0.0383] & [0.0379] \\
\hline \multirow[t]{2}{*}{ Contr. WH } & $-0.0672 * * *$ & $-0.0658^{* * *}$ & $-0.0608 * *$ & $-0.0596 * *$ & $-0.0588 * *$ & $-0.0572^{* *}$ \\
\hline & [0.0193] & [0.0192] & [0.0249] & [0.0248] & [0.0243] & [0.0243] \\
\hline \multirow[t]{2}{*}{ Contr. Fin. } & -0.0114 & -0.0159 & 0.0007 & -0.004 & -0.0075 & -0.0117 \\
\hline & [0.0208] & [0.0227] & {$[0.0235]$} & {$[0.0262]$} & [0.0301] & [0.0327] \\
\hline \multirow[t]{2}{*}{ Miscellaneous } & -0.0674 & -0.064 & $-0.0753^{*}$ & $-0.0716^{*}$ & -0.0341 & -0.0316 \\
\hline & [0.0456] & [0.0467] & [0.0373] & [0.0373] & {$[0.0600]$} & [0.0585] \\
\hline \multirow[t]{2}{*}{ Widely Held Fin. } & $-0.0470 * *$ & $-0.0396 * *$ & $-0.0463^{*}$ & -0.0386 & -0.0214 & -0.0139 \\
\hline & [0.0174] & [0.0191] & {$[0.0256]$} & {$[0.0276]$} & [0.0378] & [0.0381] \\
\hline Adjusted R-Sq. & 0.1897 & 0.1805 & 0.1775 & 0.1685 & 0.1688 & 0.1631 \\
\hline Observations & 595 & 595 & 595 & 595 & 595 & 595 \\
\hline
\end{tabular}




\section{Table 9. Regressions with Deal Form Variables}

The table presents the results of cross-sectional regressions in which the dependent variable is the targets' return in the event window $(-2,+2)$. The variables are defined in the Appendix. Clustered robust standard errors are in parenthesis. All regressions include time-fixed effects. The symbols ***,**, * denote statistical significance at the $1 \%$, $5 \%$, and $10 \%$ levels, respectively.

\begin{tabular}{|c|c|c|c|c|}
\hline & (1) & (2) & (3) & (4) \\
\hline Constant & $\begin{array}{c}-0.1352 \\
{[0.1721]}\end{array}$ & $\begin{array}{r}-0.1809 \\
{[0.1762]}\end{array}$ & $\begin{array}{r}-0.103 \\
{[0.1726]}\end{array}$ & $\begin{array}{r}-0.1455 \\
{[0.1775]}\end{array}$ \\
\hline Turnover over GDP & $\begin{array}{r}0.0578 * * * \\
{[0.0181]}\end{array}$ & & $\begin{array}{r}0.0577^{* * *} \\
{[0.0185]}\end{array}$ & \\
\hline \multicolumn{5}{|l|}{ Turnover over Mkt. } \\
\hline Cap & & $\begin{array}{r}0.0393 * * \\
{[0.0176]}\end{array}$ & & $\begin{array}{r}0.0361 * * \\
{[0.0180]}\end{array}$ \\
\hline English Origin & $\begin{array}{c}0.0457^{*} \\
{[0.0240]}\end{array}$ & $\begin{array}{r}0.0526 * * \\
{[0.0235]}\end{array}$ & $\begin{array}{c}0.0479 * \\
{[0.0262]}\end{array}$ & $\begin{array}{r}0.0575^{* *} \\
{[0.0257]}\end{array}$ \\
\hline \multicolumn{5}{|l|}{ Market Cap (\% over } \\
\hline GDP) & $\begin{array}{r}-0.0253 \\
{[0.0298]}\end{array}$ & $\begin{array}{r}0.0177 \\
{[0.0283]}\end{array}$ & $\begin{array}{r}-0.021 \\
{[0.0306]}\end{array}$ & $\begin{array}{r}0.021 \\
{[0.0288]}\end{array}$ \\
\hline Private Credit & $\begin{array}{r}0.0194 \\
{[0.0223]}\end{array}$ & $\begin{array}{r}0.0198 \\
{[0.0224]}\end{array}$ & $\begin{array}{r}0.0184 \\
{[0.0234]}\end{array}$ & $\begin{array}{r}0.0195 \\
{[0.0234]}\end{array}$ \\
\hline Log GDP & $\begin{array}{r}0.0007 \\
{[0.0193]}\end{array}$ & $\begin{array}{r}-0.0007 \\
{[0.0193]}\end{array}$ & $\begin{array}{r}-0.0004 \\
{[0.0194]}\end{array}$ & $\begin{array}{r}-0.0012 \\
{[0.0194]}\end{array}$ \\
\hline GDP Growth & $\begin{array}{r}-0.0023 \\
{[0.0040]}\end{array}$ & $\begin{array}{r}-0.003 \\
{[0.0040]}\end{array}$ & $\begin{array}{r}-0.0017 \\
{[0.0041]}\end{array}$ & $\begin{array}{r}-0.0028 \\
{[0.0042]}\end{array}$ \\
\hline Televisions & $\begin{array}{r}0.0007 \\
{[0.0010]}\end{array}$ & $\begin{array}{r}0.0012 \\
{[0.0011]}\end{array}$ & $\begin{array}{r}0.0008 \\
{[0.0010]}\end{array}$ & $\begin{array}{r}0.0012 \\
{[0.0011]}\end{array}$ \\
\hline DLLS Index & $\begin{array}{l}0.0226^{*} \\
{[0.0125]}\end{array}$ & $\begin{array}{r}0.0163 \\
{[0.0124]}\end{array}$ & $\begin{array}{c}0.0218^{*} \\
{[0.0128]}\end{array}$ & $\begin{array}{r}0.015 \\
{[0.0127]}\end{array}$ \\
\hline Domestic & $\begin{array}{r}-0.0229 \\
{[0.0187]}\end{array}$ & $\begin{array}{r}-0.0219 \\
{[0.0188]}\end{array}$ & $\begin{array}{r}-0.0217 \\
{[0.0189]}\end{array}$ & $\begin{array}{r}-0.0206 \\
{[0.0190]}\end{array}$ \\
\hline Diversifying & $\begin{array}{r}0.0105 \\
{[0.0156]}\end{array}$ & $\begin{array}{r}0.0128 \\
{[0.0159]}\end{array}$ & $\begin{array}{r}0.0117 \\
{[0.0159]}\end{array}$ & $\begin{array}{r}0.0143 \\
{[0.0163]}\end{array}$ \\
\hline Size & $\begin{array}{r}0.0038 \\
{[0.0043]}\end{array}$ & $\begin{array}{r}0.0039 \\
{[0.0043]}\end{array}$ & $\begin{array}{r}0.003 \\
{[0.0045]}\end{array}$ & $\begin{array}{r}0.0031 \\
{[0.0046]}\end{array}$ \\
\hline ROA & $\begin{array}{r}-0.001 \\
{[0.0011]}\end{array}$ & $\begin{array}{r}-0.001 \\
{[0.0011]}\end{array}$ & $\begin{array}{r}-0.001 \\
{[0.0011]}\end{array}$ & $\begin{array}{r}-0.0011 \\
{[0.0011]}\end{array}$ \\
\hline$M / B$ & $\begin{array}{r}-0.0001 \\
{[0.0004]}\end{array}$ & $\begin{array}{r}-0.0002 \\
{[0.0004]}\end{array}$ & $\begin{array}{r}-0.0001 \\
{[0.0003]}\end{array}$ & $\begin{array}{r}-0.0001 \\
{[0.0003]}\end{array}$ \\
\hline Own. Before & $\begin{array}{r}-0.0010^{* *} \\
{[0.0005]}\end{array}$ & $\begin{array}{r}-0.0010^{* *} \\
{[0.0005]}\end{array}$ & $\begin{array}{r}-0.0010^{* *} \\
{[0.0005]}\end{array}$ & $\begin{array}{r}-0.0010^{* *} \\
{[0.0005]}\end{array}$ \\
\hline Stock Price Perf. & $\begin{array}{r}-0.0538 * * * \\
{[0.0134]}\end{array}$ & $\begin{array}{r}-0.0528 * * * \\
{[0.0133]}\end{array}$ & $\begin{array}{r}-0.0541 * * * \\
{[0.0131]}\end{array}$ & $\begin{array}{r}-0.0533^{* * *} \\
{[0.0130]}\end{array}$ \\
\hline Leverage & $\begin{array}{r}-0.0473 \\
{[0.0586]}\end{array}$ & $\begin{array}{r}-0.0379 \\
{[0.0592]}\end{array}$ & $\begin{array}{r}-0.0407 \\
{[0.0627]}\end{array}$ & $\begin{array}{r}-0.0329 \\
{[0.0633]}\end{array}$ \\
\hline Cash Holdings & $\begin{array}{r}-0.001 \\
{[0.0511]}\end{array}$ & $\begin{array}{r}0.0035 \\
{[0.0514]}\end{array}$ & $\begin{array}{r}-0.006 \\
{[0.0524]}\end{array}$ & $\begin{array}{r}-0.0029 \\
{[0.0523]}\end{array}$ \\
\hline
\end{tabular}




\section{Table 9. Regressions with Deal Form Variables (Cont.)}

The table presents the results of cross-sectional regressions in which the dependent variable is the targets' cumulative abnormal return in the event window $(-2,2)$. The variables are defined in the Appendix. Clustered robust standard errors are in parenthesis. All regressions include time-fixed effects, whose coefficients are omitted. The symbols $* * *, * *, *$ denote statistical significance at the $1 \%, 5 \%$, and $10 \%$ levels, respectively.

\begin{tabular}{|c|c|c|c|c|}
\hline & (1) & (2) & (3) & (4) \\
\hline \multirow[t]{2}{*}{ Collateral } & -0.0036 & -0.0063 & -0.0062 & -0.0092 \\
\hline & [0.0350] & [0.0355] & [0.0382] & [0.0389] \\
\hline \multirow[t]{2}{*}{ Cash } & $0.0856 * * *$ & $0.0878 * * *$ & $0.0847 * * *$ & $0.0862 * * *$ \\
\hline & [0.0208] & [0.0209] & [0.0214] & [0.0215] \\
\hline \multirow[t]{2}{*}{ Taken Private } & $0.0757^{* * *}$ & $0.0793 * * *$ & $0.0751 * * *$ & $0.0791 * * *$ \\
\hline & [0.0210] & [0.0212] & [0.0213] & [0.0215] \\
\hline \multirow[t]{2}{*}{ Block } & $-0.0405^{*}$ & $-0.0417^{*}$ & $-0.0403 *$ & $-0.0420 *$ \\
\hline & [0.0230] & [0.0234] & [0.0228] & [0.0233] \\
\hline \multirow[t]{2}{*}{ Merger } & $-0.0462 * *$ & $-0.0465 * *$ & $-0.0461 * *$ & $-0.0463 * *$ \\
\hline & [0.0194] & [0.0194] & [0.0199] & [0.0199] \\
\hline \multirow[t]{2}{*}{ Open Mkt. Tr. } & -0.0401 & -0.0456 & -0.061 & -0.0616 \\
\hline & [0.0831] & [0.0833] & [0.0839] & [0.0842] \\
\hline \multirow[t]{2}{*}{ Runup } & -0.092 & -0.0928 & $-0.0990^{*}$ & $-0.1002 *$ \\
\hline & {$[0.0576]$} & [0.0579] & [0.0576] & {$[0.0580]$} \\
\hline \multirow[t]{2}{*}{ Family } & & & -0.0105 & -0.0105 \\
\hline & & & [0.0199] & [0.0201] \\
\hline \multirow[t]{2}{*}{ State } & & & -0.0077 & -0.0023 \\
\hline & & & [0.0315] & [0.0319] \\
\hline \multirow[t]{2}{*}{ Financial } & & & $-0.0551 * *$ & $-0.0561 * *$ \\
\hline & & & [0.0275] & [0.0279] \\
\hline \multirow[t]{2}{*}{ Contr. WH } & & & $-0.0636 * *$ & $-0.0623^{*}$ \\
\hline & & & [0.0322] & [0.0319] \\
\hline \multirow[t]{2}{*}{ Contr. Fin. } & & & -0.0127 & -0.0178 \\
\hline & & & [0.0319] & [0.0317] \\
\hline \multirow[t]{2}{*}{ Miscellaneous } & & & -0.0581 & -0.0493 \\
\hline & & & [0.0599] & [0.0605] \\
\hline \multirow[t]{2}{*}{ Widely Held Fin. } & & & -0.0435 & -0.0369 \\
\hline & & & [0.0441] & [0.0476] \\
\hline Adj. R-Squared & 0.1889 & 0.181 & 0.1908 & 0.1819 \\
\hline Observations & 564 & 564 & 551 & 551 \\
\hline
\end{tabular}




\section{Table 10. Regressions with Country-Level variables and Country-Fixed Effects}

The table presents the results of cross-sectional regressions in which the dependent variable is the targets' cumulative abnormal return in the event windows $(-2,2),(-5,5)$, and $(-10,10)$. The variables are defined in the Appendix. All regressions include time-fixed effects and country-fixed effects, whose coefficients are omitted. Robust standard errors clustered at country level are in parenthesis. The symbols $* * *, * *, *$ denote statistical significance at the $1 \%, 5 \%$, and $10 \%$ levels, respectively.

\begin{tabular}{lrrrrrr}
\hline & \multicolumn{2}{c}{ CAR(-2,+2) } & \multicolumn{2}{c}{ CAR(-5, +5) } & \multicolumn{2}{c}{ CAR(-10,+10) } \\
& \multicolumn{1}{c}{$(\mathbf{1})$} & \multicolumn{1}{c}{$\mathbf{( 2 )}$} & \multicolumn{1}{c}{$\mathbf{( 3 )}$} & \multicolumn{1}{c}{$\mathbf{( 4 )}$} & \multicolumn{1}{c}{$\mathbf{( 5 )}$} & \multicolumn{1}{c}{$\mathbf{( 6 )}$} \\
\hline Constant & -1.6886 & -1.8599 & -2.1714 & -2.2902 & $-3.5678^{*}$ & $-3.7308^{*}$ \\
& {$[1.3461]$} & {$[1.3902]$} & {$[1.7620]$} & {$[1.7710]$} & {$[2.0646]$} & {$[2.0833]$} \\
Turnover over GDP & $0.0594^{* * *}$ & & $0.0555^{* * *}$ & & $0.0632^{* * *}$ & \\
& {$[0.0133]$} & & {$[0.0137]$} & & {$[0.0151]$} & \\
Turnover over Mkt. Cap & & $0.0479^{* * *}$ & & $0.0365^{* *}$ & & $0.0471^{* *}$ \\
& & {$[0.0160]$} & & {$[0.0165]$} & & {$[0.0194]$} \\
Market Cap. (\% over GDP) & -0.0278 & 0.0166 & -0.0219 & 0.0196 & -0.0275 & 0.0198 \\
& {$[0.0307]$} & {$[0.0337]$} & {$[0.0335]$} & {$[0.0352]$} & {$[0.0405]$} & {$[0.0388]$} \\
Private Credit & 0.0277 & 0.0362 & 0.0418 & $0.0498^{*}$ & 0.0127 & 0.0218 \\
& {$[0.0320]$} & {$[0.0282]$} & {$[0.0297]$} & {$[0.0263]$} & {$[0.0260]$} & {$[0.0245]$} \\
Log GDP & 0.1861 & 0.1991 & 0.2369 & 0.245 & $0.3879 *$ & $0.3997^{*}$ \\
& {$[0.1438]$} & {$[0.1476]$} & {$[0.1864]$} & {$[0.1872]$} & {$[0.2180]$} & {$[0.2198]$} \\
GDP Growth & -0.0022 & -0.0019 & -0.0027 & -0.0025 & 0.0002 & 0.0004 \\
& {$[0.0035]$} & {$[0.0035]$} & {$[0.0029]$} & {$[0.0029]$} & {$[0.0030]$} & {$[0.0029]$} \\
Adjusted R-squared & & & & & & 0.0029 \\
Observations & 0.099 & 0.0965 & 0.0922 & 0.0891 & 0.0435 & 0.041 \\
& 1119 & 1119 & 1119 & 1119 & 1119 & 1119 \\
& & & & & & \\
\hline
\end{tabular}


Table 11. Regressions with Country-Fixed Effects

The table presents the results of cross-sectional regressions in which the dependent variable is the targets' cumulative abnormal return in the event windows $(-2,2),(-5,5)$, and $(-10,10)$. The variables are defined in the Appendix. Robust standard errors clustered at country level are in parenthesis. All regressions include time-fixed effects and country-fixed effects, whose coefficients are omitted. The symbols $* * *, * *, *$ denote statistical significance at the $1 \%, 5 \%$, and $10 \%$ levels, respectively.

(1)

CAR $(-2,+2)$
CAR $(-5,+5)$

(3)
(2)

$\begin{array}{lr}\text { Constant } & -0.6941 \\ & {[1.6955]} \\ \text { Turn. over GDP } & 0.0763 * * * \\ & {[0.0171]}\end{array}$

Turn. Mkt Cap

Mkt Cap(\%GDP)

Private Credit

Log GDP

GDP Growth

Domestic

Diversifying

Size

ROA

M/B

Own. Before

Stock P.Perf.

Leverage

Cash Holdings

Collateral

Cash

Taken Private

Runup

Adjusted R-Sq.

Observations
$-1.0801$

[1.7496]

$0.0486^{*}$

[0.0246]

0.0114

[0.0357]

0.0358

[0.0418]

0.0741

[0.1795]

0.0044

[0.0045]

$-0.025$

[0.0172]

0.003

[0.0104]

0.0029

[0.0034]

$-0.0001$

[0.0005]

$-0.0003$

[0.0003]

$-0.0008$

[0.0006]

$-0.0433 * * *$

[0.0123]

$-0.0628$

[0.0539]

0.0121

[0.0359]

0.0087

[0.0264]

$0.1001^{* * *}$

[0.0240]

$0.0825 * * *$

[0.0216]

$-0.1036$

[0.0643]

0.1694

673
[0.0334]

0.0392

[0.0390]

0.1091

[0.1846]

0.0042

[0.0046]

$-0.025$

[0.0170]

0.0041

[0.0102]

0.0029

[0.0037]

$-0.0002$

[0.0005]

$-0.0004$

[0.0003]

$-0.0008$

[0.0006]

$-0.0417^{* * *}$

[0.0124]

$-0.0643$

[0.0541]

0.0178

[0.0352]

0.0074

[0.0268]

$0.0989 * * *$

[0.0240]

$0.0822^{* * *}$

[0.0217]

$-0.1044$

[0.0654]

0.1617

673
(4)

$-1.5494$

[2.1505]

[2.1669]

$0.0825 * * *$

[0.0189]

0.0579**

[0.0218]

$-0.0015$

[0.0365]

0.0559

[0.0387]

0.1543

[0.2243]

0.0049

[0.0043]

$-0.0295^{*}$

[0.0170]

$-0.0046$

[0.0110]

0.0034

[0.0044]

0.0001

[0.0006]

$-0.0005^{* *}$

[0.0003]

$-0.0006$

[0.0007]

$-0.0424 * * *$

[0.0107]

$-0.0879 *$

[0.0521]

0.0446

[0.0320]

$-0.0154$

[0.0223]

$0.1015^{* * *}$

[0.0238]

$0.0759 * * *$

[0.0241]

0.0139

[0.0827]

0.1675

673$$
673
$$

CAR $(-10,+10)$

(5)

(6)

$$
\begin{array}{rr}
-2.3201 & -2.7847 \\
{[2.8460]} & {[2.7635]} \\
0.0874^{* * *} & \\
{[0.0230]} & \\
& 0.0678^{* * *} \\
& {[0.0250]} \\
-0.0316 & 0.0282 \\
{[0.0557]} & {[0.0489]} \\
0.0195 & 0.0241 \\
{[0.0373]} & {[0.0361]} \\
0.2479 & 0.2901 \\
{[0.2969]} & {[0.2886]} \\
0.0055 & 0.0055 \\
{[0.0048]} & {[0.0046]} \\
-0.0509 * * & -0.0508 * * \\
{[0.0205]} & {[0.0203]} \\
-0.0056 & -0.0047 \\
{[0.0137]} & {[0.0137]} \\
0.0027 & 0.0025 \\
{[0.0051]} & {[0.0054]} \\
0.0002 & 0.0002 \\
{[0.0008]} & {[0.0008]} \\
-0.0006 * * & -0.0007 * * \\
{[0.0003]} & {[0.0003]} \\
-0.0002 & -0.0002 \\
{[0.0007]} & {[0.0007]} \\
-0.0428 * * * & -0.0408 * * * \\
{[0.0093]} & {[0.0097]} \\
-0.1379 & -0.1392 * \\
{[0.0828]} & {[0.0826]} \\
0.0188 & 0.0246 \\
{[0.0335]} & {[0.0341]} \\
-0.005 & -0.0058 \\
{[0.0254]} & {[0.0263]} \\
0.0930 * * * & 0.0917 * * * \\
{[0.0264]} & {[0.0265]} \\
0.0841 * * * & 0.0834 * * * \\
{[0.0268]} & {[0.0272]} \\
0.1942 * * & 0.1938 * * \\
{[0.0813]} & {[0.0827]} \\
0.1847 & 0.1799 \\
673 & 673
\end{array}
$$$$
\begin{array}{lll}
{[0.0003]} & {[0.0003]} & {[0.0003]} \\
-0.0006 & -0.0002 & -0.0002
\end{array}
$$$$
[0.0007] \quad[0.0007] \quad[0.0007]
$$$$
\begin{array}{lll}
-0.0406 * * * & -0.0428 * * * & -0.0408 * * *
\end{array}
$$$$
\text { [0.0109] [0.0093] [0.0097] }
$$$$
\begin{array}{lll}
-0.0894 * & -0.1379 & -0.1392 *
\end{array}
$$$$
\text { [0.0522] [0.0828] [0.0826] }
$$$$
\begin{array}{lll}
0.0504 & 0.0188 & 0.0246
\end{array}
$$$$
[0.0313] \quad[0.0335] \quad[0.0341]
$$$$
\begin{array}{lll}
-0.0164 & -0.005 & -0.0058
\end{array}
$$$$
\text { [0.0231] [0.0254] [0.0263] }
$$$$
0.1002^{* * *} \quad 0.0930^{* * *} \quad 0.0917^{* * *}
$$$$
\left[\begin{array}{lll}
{[0.0240]} & {[0.0264]} & {[0.0265]}
\end{array}\right.
$$$$
0.0754 * * * \quad 0.0841^{* * *} \quad 0.0834 * * *
$$$$
\text { [0.0246] [0.0268] [0.0272] }
$$$$
0.0133 \quad 0.1942 * * \quad 0.1938^{* *}
$$$$
\left[\begin{array}{lll}
0.0839] & {[0.0813]} & {[0.0827]}
\end{array}\right.
$$$$
\begin{array}{lll}
0.1608 & 0.1847 & 0.1799
\end{array}
$$ 